\title{
Variant profiles of genes mapping to chromosome 16q loss in Wilms tumors reveals link to cilia-related genes and pathways
}

\author{
Eiko Kitamura ${ }^{1}$, John K. Cowell ${ }^{1}$, Chang-Sheng Chang ${ }^{1}$ and Lesleyann Hawthorn ${ }^{1}$ \\ ${ }^{1}$ Georgia Cancer Center, Augusta University, Augusta, GA, USA \\ Correspondence to: Lesleyann Hawthorn, email: Ihawthorn@augusta.edu \\ Keywords: Wilms tumor, chromosome 16q, cilia-related genes, cilia pathways \\ Received: July 06, $2020 \quad$ Accepted: September 08, $2020 \quad$ Published: October 06, 2020
}

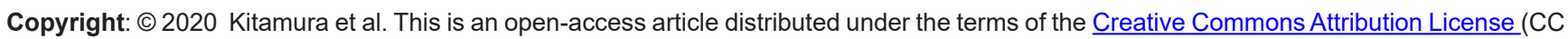
BY 3.0), which permits unrestricted use, distribution, and reproduction in any medium, provided the original author and source are credited.

\section{ABSTRACT}

Background: Wilms tumor is the most common pediatric renal tumor and the fourth most common malignancy in children. Chromosome 16q deletion(del) or loss of heterozygosity ( $\mathrm{LOH}$ ) has been correlated with recurrence and overall poor prognosis, such that patients with $16 q$ LOH and $1 \mathrm{p}$ allelic loss are treated with more aggressive chemotherapeutic regimens.

Methods: In the present study, we have compared the variant profiles of Wilms tumors with and without 16q del/LOH using both data available from the TARGET database (42 samples) and tumors procured from our legacy collection ( 8 samples). Exome-Seq data was analyzed for tumor specific variants mapping to $\mathbf{1 6 q}$. Whole exome analysis was also performed. An unbiased approach for somatic variant analysis was used to detect tumor-specific, somatic variants.

Results: Of the 72 genes mapping to $16 q, 42 \%$ were cilia-related genes and $\mathbf{2 8} \%$ of these were found to carry somatic variants specific to those tumors with $16 q d e l / L O H$. Whole exome analyses further revealed that $30 \%$ of cilia-related genes across the genome carried alterations in tumors both with and without 16qdel/LOH. Additional pathway analyses revealed that many cilia-related pathway members also carried deleterious variant in these tumors including Sonic Hedgehog (SHh), Wnt, and Notch signaling pathways.

Conclusions: The data suggest that cilia-related genes and pathways are compromised in Wilms tumors. The genes on chromosome 16q that carry deleterious variants in cilia-related genes may account for the more aggressive nature of tumors with 16q del/LOH.

\section{INTRODUCTION}

Wilms tumor (WT) is the fourth most common pediatric cancer and affects approximately 1 in 10,000 children in Europe and North America. It typically presents as a complex embryonal tumor with triphasic histology (blastemic, epithelial and stromal components) and may also display cartilage, osteoid, and neural elements adding to the complexity of these tumors [1]. Although having a relatively good overall survival $(>90 \%)$, due to a combination of surgery and more recently radiation/chemotherapy, there is also a subgroup of patients with poorer overall survival [2]. The stage at diagnosis is important to some extent in this determination, as is the histological subtype. WT show favorable (FHWT) or diffuse anaplastic (DAWT) histology, where the anaplastic histology is defined by the presence of atypical, polyploidy mitotic figures, large nuclei and hyperchromasia [3]. Bilateral tumors, usually associated with hereditary forms of the disease, cannot be treated with bilateral resection and therefore need alternative therapeutic strategies [4]. There is no apparent correlation between histology subtype and tumor stage, and only $50 \%$ of children that suffer relapse will survive. 
In addition, there is a high incidence of late radiation morbidity in patients undergoing adjuvant radiotherapy for Wilms tumor, significant adverse events and treatmentrelated risk factors in long-term Wilms tumor survivors and a high risk of second malignant neoplasms, presumed to be due to treatment.

Studies aimed at defining the molecular characteristics of relapsing WTs have identified abnormalities associated with poor outcomes including loss of heterozygosity $(\mathrm{LOH})$ at $16 \mathrm{q}[5,6]$.

These observations have been confirmed by several groups in large studies in the National Wilms' Tumor Study Group (NWTSG) study groups 3 and 4 as well as the United Kingdom Children's Cancer Study Group (UKCCSG) studies $[6,7]$. In the prospective NWTSG5 study, involving >2000 samples, 16\% showed 16q $\mathrm{LOH}$, and a significant correlation was found between poor prognosis and relapse within 2 years of treatment [5]. Additionally, LOH at $16 \mathrm{q}$ has been associated with a 2.7-fold increased risk of death in favorable histology tumors [6]. Moreover, a recent meta-analysis involving 10 studies and 3385 patients concluded that $\mathrm{LOH}$ at $16 \mathrm{q}$ was significantly associated with WT relapse in both histological subtypes [8]. These studies now clearly demonstrate that there is a subset of WT that are dependent on genetic events on $16 \mathrm{q}$ which determine poor outcome. Chromosome 16q and/or 1p allelic loss status are used to classify patients within the NWTSG therapeutic protocol to receive more rigorous chemotherapies $[3,5]$.

Knudson's landmark 'two hit hypothesis' [9] provided proof-of-principle that tumor suppressor genes could be identified by examining genes mapping to single allele deletions accompanied by variants in second alleles at these loci. However, attempts to identify loci at chromosome 16q have largely been futile due to the extensive regions of $\mathrm{LOH}$ typically observed, possibly suggesting that several genes may act in concert to contribute to the more aggressive phenotype.

We have used data generated through the Therapeutically Applicable Research to Generate Effective Treatments (TARGET) initiative, which has enabled comprehensive characterization of high-risk Wilms tumor cases, defined as having either favorable histology (FHWT) that relapsed or diffuse anaplasia (DAWT). These samples were combined with a legacy set of samples to define variant-containing genes on chromosome 16 which may contribute to Wilms' tumorigenesis or the more aggressive nature of tumors with $16 \mathrm{q} \mathrm{del} / \mathrm{LOH}$. As a result, it became apparent that a large percentage of the tumor-specific variants detected in WT with 16q loss and/or LOH affected genes that encoded cilia- related proteins. A more extensive genome analysis beyond chromosome 16 demonstrated tumor-specific, variants in additional genes associated with ciliogenesis.

\section{RESULTS}

\section{Microarray analysis of copy number and LOH}

(Figure 1) shows the experimental layout in order to clarify the number and types of samles used in each of the experiments. In our previous study [10] we defined three types of $16 \mathrm{q}$ abnormality; deletion with accompanying $\mathrm{LOH}, \mathrm{LOH}$ without $16 \mathrm{q}$ deletion and copy number abnormalities (CNA) without $\mathrm{LOH}$, presumably resulting from chromosome loss from a tetraploid cell. Of 69 paired samples from the TARGET project, 32 (46\%) carried either deletions or LOH involving 16q, which included 24 samples with deletion associated with a $\mathrm{LOH}(35 \%)$ and 8 samples (11\%) carrying deletions without accompanying LOH (Figure 2).

Deletions with accompanying LOH extended the entire length of $16 \mathrm{q}$, while deletions without accompanying LOH, localized to chr16q11.2 (46506039$46539392)$ and $16 \mathrm{q} 24.3$ (90158838-90287536). These

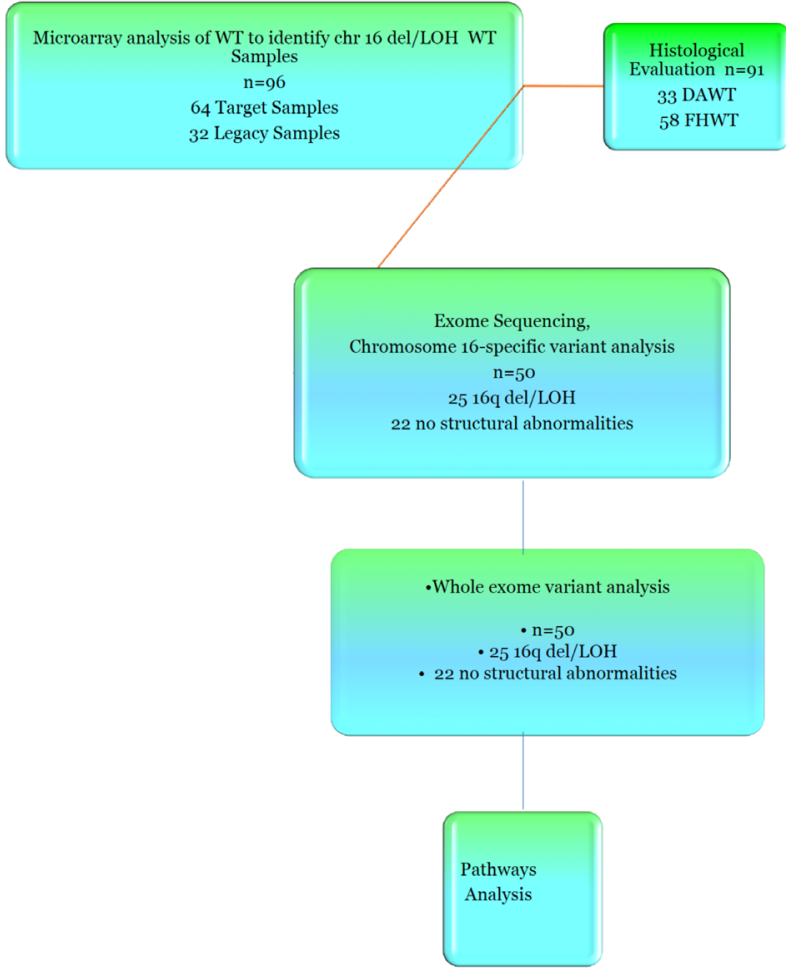

Figure 1: Flow Chart of Experiments. Experiments began with the use of SNP microarrays to identify samples with chromosome $16 \mathrm{qdel} / \mathrm{LOH}$. We analyzed these samples for histological correlates. Exome sequencing was then performed, and variants located on chromosome 16q were analyzed. Whole genome exome analysis was then carried out, followed by pathways analysis. 


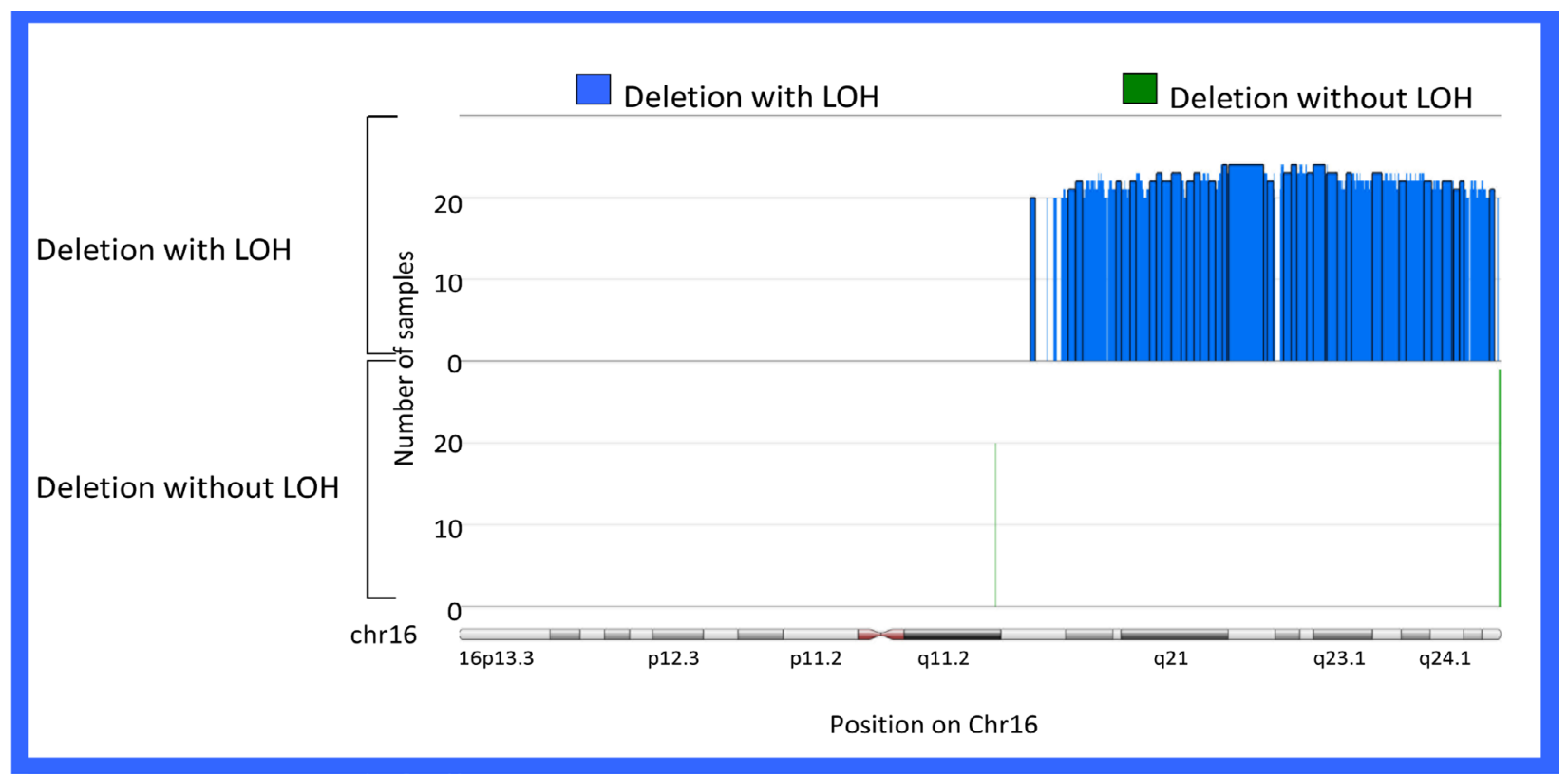

Figure 2: Regions of Loss/LOH on Chr16q. Depiction of chromosome 16 showing regions where commonly changed in more than 20 samples. The Y-axis represents number of samples harboring deletion with $\mathrm{LOH}$ or deletion without $\mathrm{LOH}$ and the $\mathrm{x}$-axis shows position on chr16. Deletion with accompanying LOH was observed in 24/69 Wilms tumor samples (blue). Also shown are regions of deletion without LOH in 8/69 samples (green). Overall, 46\% of samples carried structural abnormalities on Chr16.

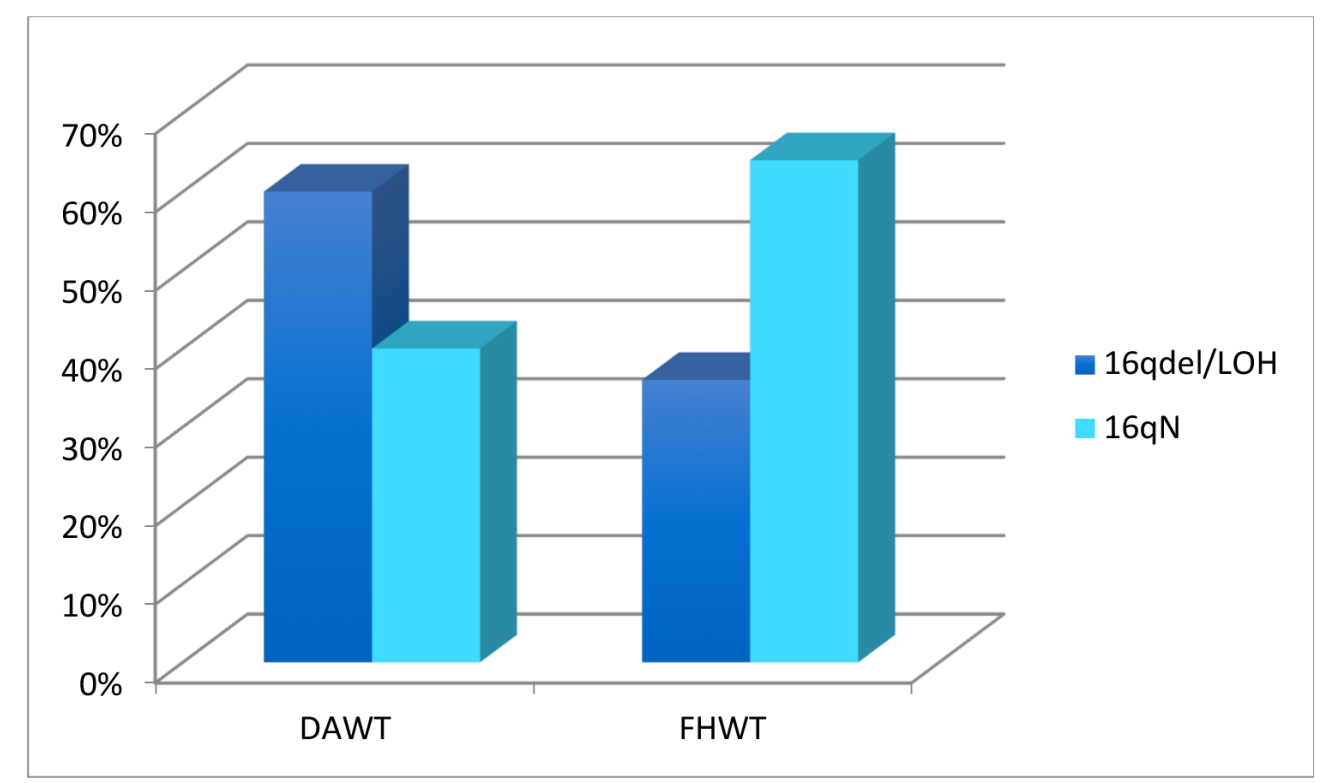

Figure 3: Histology as a Function of Chromosome 16q Status. Graph comparing WT samples between 16qdel/LOH and 16qN in DAWT or FHWT histological subtypes. The y-axis indicates percentage of samples with16qdel/LOH and 16qN observed in each

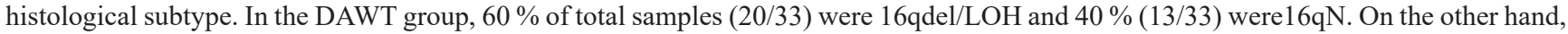
$36 \%$ of FHWT samples $(21 / 58)$ were $16 \mathrm{qdel} / \mathrm{LOH}$ while $64 \%(37 / 58)$ were $16 \mathrm{qN}$. 
Table 1: Genes Mapping to Chromosome 16q Frequently Altered genes in WT. Shown are the 20 top genes of a total 91 carrying one or more homozygous somatic variants that are predicted to be damaging and/or deleterious at the protein level.

\begin{tabular}{|c|c|c|c|}
\hline Gene Symbol & $\begin{array}{l}\# \\
\text { Samples } \\
\text { in all } 50 \\
\text { Samples }\end{array}$ & $\begin{array}{l}\text { \# Samples in } \\
25 \quad 16 q d e l / \\
\text { LOH Samples }\end{array}$ & $\begin{array}{l}\# \quad \text { Samples } \\
\text { in } 22 \quad 16 q N \\
\text { Samples }\end{array}$ \\
\hline HYDIN & 8 & 7 & 1 \\
\hline NQO1 & 8 & 8 & 0 \\
\hline$D R C 7$ & 7 & 7 & 0 \\
\hline ADAMTS18 & 6 & 5 & 1 \\
\hline $\mathrm{CDH} 3$ & 6 & 6 & 0 \\
\hline KCNG4 & 6 & 6 & 0 \\
\hline ZNF778 & 6 & 6 & 0 \\
\hline CTU2 & 5 & 4 & 1 \\
\hline MT1A & 5 & 5 & 0 \\
\hline PKD1L2 & 5 & 4 & 1 \\
\hline PMFBP1 & 5 & 4 & 1 \\
\hline TAF1C & 5 & 4 & 1 \\
\hline ZNF19 & 5 & 5 & 0 \\
\hline$A B C C 12$ & 4 & 4 & 0 \\
\hline$A C S F 3$ & 4 & 4 & 0 \\
\hline BCMO1 & 4 & 4 & 0 \\
\hline $\mathrm{CDH11}$ & 4 & 4 & 0 \\
\hline$C N G B 1$ & 4 & 4 & 0 \\
\hline PHLPP2 & 4 & 4 & 0 \\
\hline $\mathrm{ZCCHCl4}$ & 4 & 3 & 1 \\
\hline
\end{tabular}

tumors are now collectively termed $16 \mathrm{qdel} / \mathrm{LOH}$ samples. Combining the TARGET data with that previously reported (Hawthorn and Cowell 2011), 96 samples were available for analysis (Supplemental Table 1).

Within this series of tumors, both histological evaluation and assessment of chromosome $16 \mathrm{q}$ status was available from 91 cases, consisting of 33 with DAWT and 58 with FHWT. 60\% (20/33) of tumors with DAWT histology and $36 \%(21 / 58)$ with the FHWT histological subtype had loss/deletion of chromosome 16q . Figure 3 shows that structural abnormalities of $16 \mathrm{q}$ are significantly associated with the DAWT histology (Welch 2-sided $t$-test $p=0.02$ ).

\section{Variants detected in WT}

Exome-Seq data from 50 WT samples was analyzed, 42 samples from the TARGET project and 8 samples from the legacy collection. The annotated variants were filtered for predicted functional effects as outlined in the Materials and Methods section and categorized into missense variants, frameshifts, deletions/insertions and stop gain/losses. A total of 24,271 heterozygous-/ homozygous- somatic variants predicted as Damaging and/or Deleterious were identified in 10,789 genes. The full list of somatic variants is available in Supplemental Table S2. It should be noted that the number of variants are higher than other published works due to the fact that we did not filter out variants that were listed in dbSNP but instead focused on variants that were present in the tumors and not in the matched normal samples, ie "tumorspecific/somatic".

To examine the variant profiles in the $16 \mathrm{qdel} / \mathrm{LOH}$ samples, exome data from 50 samples were analyzed, 25 of which were $16 q d e 1 / \mathrm{LOH}$ and 22 with no structural abnormalities of $16 \mathrm{q}$ and three that had no accompanying copy number data available. Using the pipeline described in the Materials and Methods section, we identified 131 homozygous or hemizygous in the samples with allelic loss, somatic variants in 91 genes that mapped to $16 \mathrm{q}$ in the $16 \mathrm{qdel} / \mathrm{LOH}$ samples. Chromosome $16 \mathrm{~N}$ tumors carried somatic variants in 13 genes, 10 of which overlapped with the variants in the 16 qdel/LOH samples and 3 genes that were unique. The $16 \mathrm{qdel} / \mathrm{LOH}$ group carried a median of 8.1 (homozygous or hemizygous in the samples with allelic loss, deleterious/damaging) variant-containing genes mapping to chromosome $16 \mathrm{q}$ per patient, while $16 \mathrm{qN}$ group carried a median of 0.59 genes per patient (See Figure 4). The top 20 variantcontaining genes are shown in Table 1. The complete list of all somatic variants mapping to $16 \mathrm{q}$ in tumors with and without 16q abnormalities is available in Supplemental Table S3.

As envisaged, the number of variants-containing genes mapping to chromosome $16 \mathrm{q}$ is higher in the DAWT group. Figure $4 \mathrm{~b}$ shows that there is also a statistically significant difference $(p=0.07)$ between the number of variant-containing genes carried by the patients with DAWT (median $=5.8$ genes $/$ patient) compared with patients with FHWT (median=2.7 genes/patient). There are 33 genes overlapping between the 2 histological subtypes, 31 uniquely altered in the DAWT and 18 unique to the FHWT subtypes.

Analysis of gene classification using GO Genesets in GSEA revealed that GO-Cilium was significantly $(q=$ $3.5^{\mathrm{e}-2}$ ) enriched in the 91 variant-containing genes mapping to $16 \mathrm{q}$. The CilDB was then queried using chromosome location and 60 genes were identified that mapped to chr16q. The 91 chromosome $16 \mathrm{q}$ variant-containing genes were then cross-referenced with those in the CilDB which identified 12 that overlapped (see Figure 5). Of note, however, many of these genes are included in the CilDB as a result of genome-wide transcript expression analyses and have not been fully validated as having cilia-related functionality. We, therefore, further curated genes that had also been reported in the literature as 'cilia-related', by GO functional categorization and the DAVID functional annotation tool. 


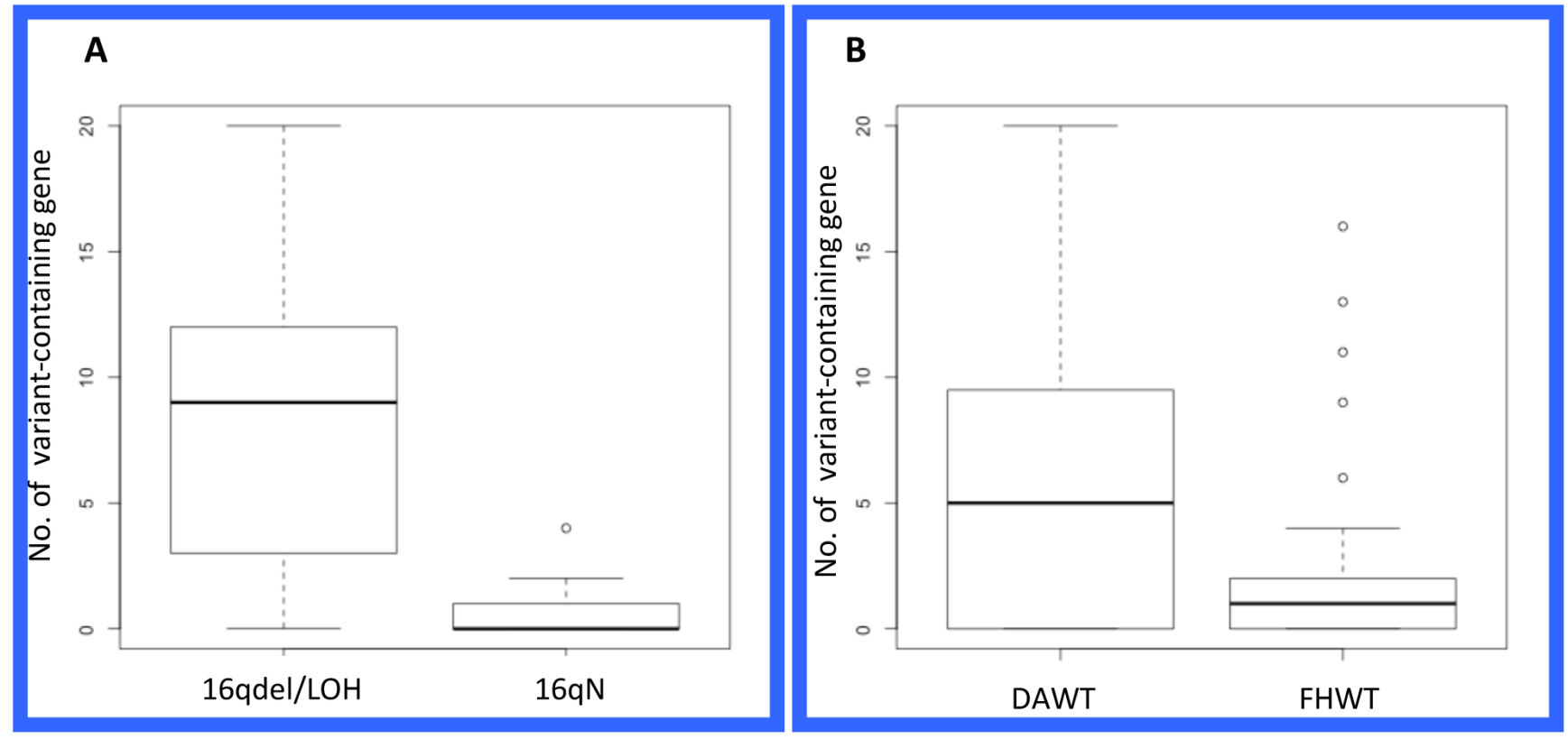

Figure 4: Box Plots of Sample Characteristics and Somatic Variants at Chromosome 16q. A. The box plot displays16qdel/ LOH group having a median of 8.1 (homozygous, deleterious/damaging) variant-containing genes/patient mapping to chromosome $16 \mathrm{q}$ and the $16 \mathrm{qN}$ group having a median of 0.59 variant-containing genes/patient. The difference between the two groups is significant at $p=$ $2.9 \mathrm{e}-07$ using a Welch two-sample $t$-test. B. Box plot shows that the median number of variant-containing genes is more prevalent in DAWT histological class (5.8 / patient) than on the FHWT class (2.7 /patient). The difference is significant at $p=0.07$ using a Welch two-sample $t$-test.

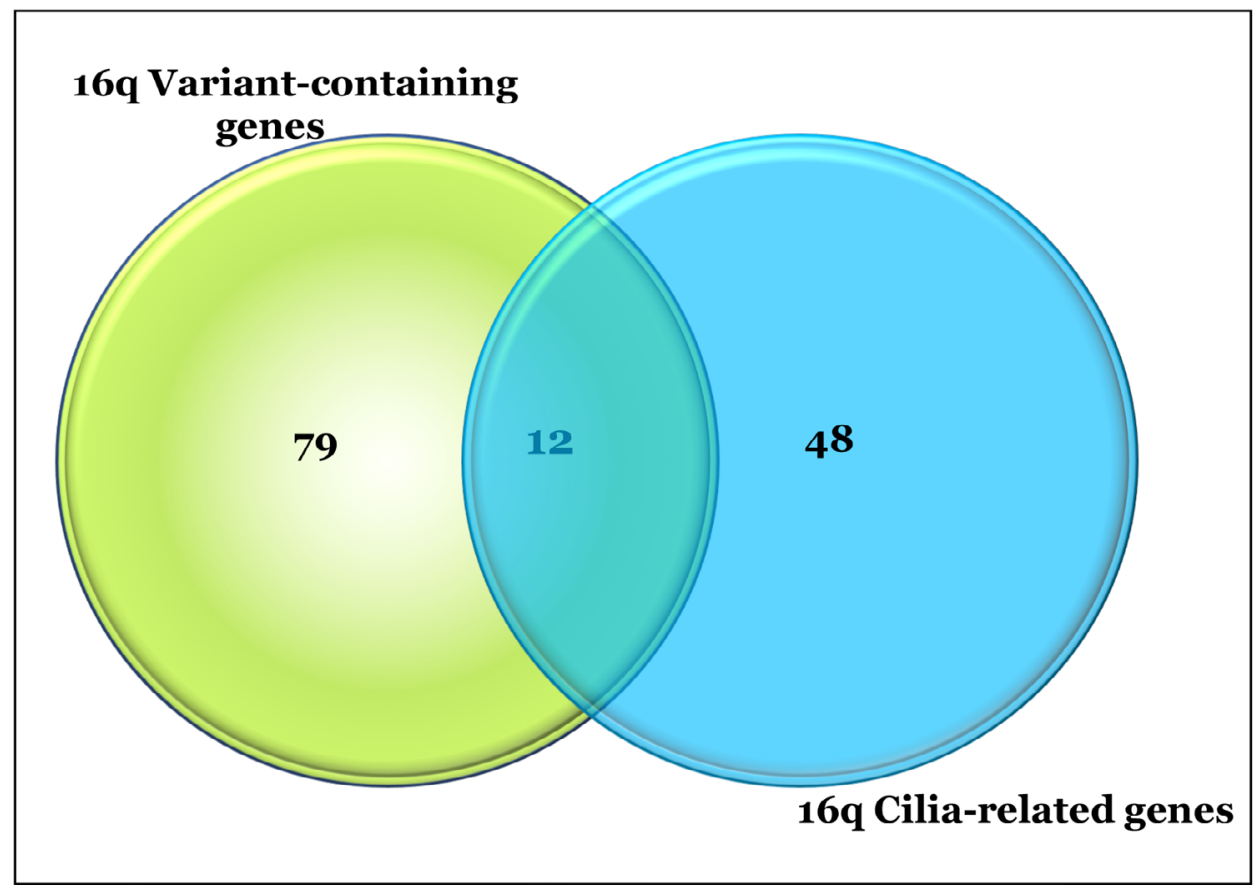

Figure 5: Venn Diagram of Cilia-related Genes Mapping to Chr 16q. The diagram shows the overlap of 60 Cilia-related genes mapping to chromosome 16q (in red) and the 91 variant-containing genes detected using our analysis (in blue). The overlap between the two groups is 12 genes. 
Table 2: List of Cilia-Related Genes Mapping to 16q. List of cilia-related genes mapping to 16q and carrying somatic variants in the 50 listed samples. 16qdel/LOH samples are shaded in blue while $16 \mathrm{qN}$ samples are shaded in red. The samples shaded in grey have no copy number information available. The purple- shaded boxes denote those samples that have homozygous or hemizygous in LOH samples that are deleterious/damaging variants in the genes listed along the top. It is notable that the vast majority of these occur in 16qdel/LOH samples and only $116 \mathrm{qN}$ sample has variants in any of these genes.

\begin{tabular}{|c|c|c|c|c|c|c|c|c|c|c|c|c|c|c|c|c|c|c|c|c|c|c|c|c|c|c|c|}
\hline 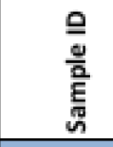 & $\begin{array}{l}\mathrm{O} \\
\mathrm{o} \\
\mathrm{g}\end{array}$ & 苞 & $\frac{\frac{5}{5}}{\frac{5}{5}}$ & 站 & \begin{tabular}{l}
$\infty$ \\
\multirow{5}{*}{} \\
\end{tabular} & 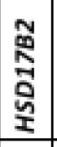 & 於 & $\frac{6}{\mathrm{~g}}$ & $\begin{array}{l}\frac{4}{7} \\
08 \\
\frac{10}{2} \\
\frac{1}{2}\end{array}$ & $\begin{array}{l}\tilde{g} \\
\mathbf{g} \\
z\end{array}$ & 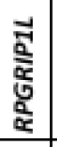 & 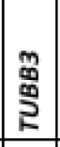 & 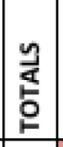 & 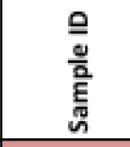 & \begin{tabular}{|l|} 
\\
\\
$\frac{\sigma}{a}$ \\
\end{tabular} & 岃 & $\frac{n}{5}$ & 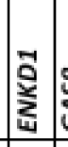 & 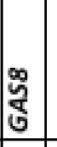 & 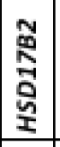 & $\frac{3}{2}$ & 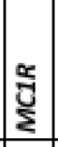 & $\begin{array}{l}\frac{4}{7} \\
09 \\
\frac{10}{20} \\
\frac{9}{2} \\
\end{array}$ & $\frac{1}{g}$ & $\mid \begin{array}{l}\vec{z} \\
\frac{a}{c} \\
\frac{c}{0} \\
\frac{a}{c} \\
c\end{array}$ & 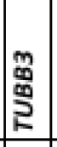 & 诰 \\
\hline CAAAAA & & & & & & & & & & & & & 2 & CAAAAR & & & & & & & & & & & & & 0 \\
\hline CAAAAP & & & & & & & & & & & & & 2 & Gos54 & & & & & & & & & & & & & 0 \\
\hline GOS 100 & & & & & & & & & & & & & 0 & PADXAY & & & & & & & & & & & & & 0 \\
\hline Gos 11 & & & & & & & & & & & & & 2 & PADZUB & & & & & & & & & & & & & 0 \\
\hline GOS 132 & & & & & & & & & & & & & 0 & PAEAFB & & & & & & & & & & & & & 0 \\
\hline Gos32 & & & & & & & & & & & & & 1 & PAILKR & & & & & & & & & & & & & 0 \\
\hline Gos52 & & & & & & & & & & & & & 0 & PAILN」 & & & & & & & & & & & & & 0 \\
\hline GOS576 & & & & & & & & & & & & & 4 & PANMUT & & & & & & & & & & & & & 0 \\
\hline Gos900 & & & & & & & & & & & & & 4 & PAJMKN & & & & & & & & & & & & & 0 \\
\hline PAILKC & & & & & & & & & & & & & 2 & PAJMVC & & & & & & & & & & & & & 0 \\
\hline PAILWT & & & & & & & & & & & & & 0 & PAJNGH & & & & & & & & & & & & & 0 \\
\hline PAJMIZ & & & & & & & & & & & & & 1 & PAJNLT & & & & & & & & & & & & & 2 \\
\hline PAJMLZ & & & & & & & & & & & & & 0 & PAJNRH & & & & & & & & & & & & & 0 \\
\hline PAIMSE & & & & & & & & & & & & & 2 & PAJPCM & & & & & & & & & & & & & 0 \\
\hline PAINNR & & & & & & & & & & & & & 1 & PAJPDC & & & & & & & & & & & & & 0 \\
\hline PANNUP & & & & & & & & & & & & & 4 & PAKFYV & & & & & & & & & & & & & 0 \\
\hline \begin{tabular}{|l} 
PAINVE \\
\end{tabular} & & & & & & & & & & & & & 2 & PAKKNS & & & & & & & & & & & & & 0 \\
\hline PAKECR & & & & & & & & & & & & & 0 & PAKMSV & & & & & & & & & & & & & 0 \\
\hline PAKPDF & & & & & & & & & & & & & 2 & PAKVET & & & & & & & & & & & & & 0 \\
\hline PAKULH & & & & & & & & & & & & & 3 & PAKXWB & & & & & & & & & & & & & 0 \\
\hline \begin{tabular}{|l|} 
PAKXXF \\
\end{tabular} & & & & & & & & & & & & & 1 & PALFME & & & & & & & & & & & & & 0 \\
\hline PAKYLT & & & & & & & & & & & & & 0 & PAUIP & & & & & & & & & & & & & 0 \\
\hline PALDTE & & & & & & & & & & & & & 2 & PAJMEP & & & & & & & & & & & & & 0 \\
\hline PALGLU & & & & & & & & & & & & & 1 & PANNNC & & & & & & & & & & & & & 0 \\
\hline PALLCK & & & & & & & & & & & & & 0 & PAINTJ & & & & & & & & & & & & & 0 \\
\hline Totals & 8 & 1 & 2 & 1 & 1 & 1 & 7 & 2 & 2 & 8 & 1 & 2 & & Totals & 0 & 0 & 0 & 0 & 0 & 0 & 1 & 0 & 1 & 0 & 0 & 0 & \\
\hline
\end{tabular}

Table 2 shows 12 of the cilia-related genes which contain somatic variants. Notably, 17/25 16qdel/LOH samples carry variants in cilia-related genes mapping to $16 q$. It is noteworthy that only one patient without a $16 \mathrm{q}$ abnormality carried homozygous somatic variants in any of these genes.

\section{Whole exome analysis of WT}

Given the overwhelming number of cilia-related genes on chromosome $16 \mathrm{q}$ that carried somatic variants, we extended the variant profiles of cilia-related genes to the entire exome and also determined whether there was a difference in variant profiles between tumors with ( $n$ $=25)$ and without $(n=22) 16 q$ structural abnormalities. 23,429 variants were detected in the 47 tumor samples that were predicted to be detrimental at the protein level as outlined in the Materials and Methods. A total of 4960 and 4679 genes respectively carried somatic variants in two or more samples with and without $16 \mathrm{q}$ abnormalities and 3577 genes overlapped between the two groups. Of these, 1383 and 1102 genes respectively were unique to the tumors with and without $16 \mathrm{q}$ abnormalities. Table 3 shows the 30 most frequently altered genes for each of these groups. The complete list of somatic variants is available in Supplemental Table 2.

Analysis using the CilDB showed a large number of genes overlapping with cilia-related functions from tumors with and without $16 \mathrm{q}$ abnormalities and these findings are shown in Figure 6, where it can be seen that 570 genes in both sample types overlap with CilDB genes, 141 are unique samples with no $16 \mathrm{q}$ abnormalities and 202 uniquely overlap between the $16 \mathrm{qdel} / \mathrm{LOH}$ and the CilDB. The genes that comprise each of the overlaps are defined in Supplemental Table S4A.

Interestingly, genes that carried variants in the $16 q d e l / L O H$ samples were identified by this analysis as having deleterious variants in tumors with and without $16 \mathrm{q}$ abnormalities. For example, the HYDIN gene had homozygous, somatic variants in $7 / 2516 q d e l / L O H$ 
Table 3: List of Frequently Altered Genes. Genes most frequently altered across the genome in WT samples for both $16 \mathrm{qdel} / \mathrm{LOH}$ and $16 \mathrm{qN}$ tumors. Genes were identified using Exome-seq and the analysis pipeline described in Materials and Methods. The most frequently altered genes overlap substantially between the two groups.

\begin{tabular}{|c|c|c|c|}
\hline Gene Symbol & $\begin{array}{l}\text { \%16qdel/LOH } \\
\text { Samples with } \\
\text { Somatic variants }\end{array}$ & Gene Symbol & \begin{tabular}{|l|}
$\% 16 q N$ \\
Samples \\
with \\
Somatic \\
variants
\end{tabular} \\
\hline GPRIN2 & 100 & GPRIN2 & 100 \\
\hline KCNJ12 & 100 & KCNJ12 & 100 \\
\hline MAP2K3 & 100 & MAP2K3 & 100 \\
\hline$O B S C N$ & 100 & OR4C3 & 100 \\
\hline OR $4 C 3$ & 100 & PDE4DIP & 100 \\
\hline PDE 4DIP & 100 & $B C L A F 1$ & 95.5 \\
\hline$B C L A F 1$ & 96 & DNAH5 & 95.5 \\
\hline GPR98 & 96 & KRT32 & 95.5 \\
\hline$N E B$ & 96 & $M U C 3 A$ & 95.5 \\
\hline$N R A P$ & 96 & $N E B$ & 95.5 \\
\hline$C A C N A 1 B$ & 92 & $S C G B 1 C 1$ & 95.5 \\
\hline$R H B G$ & 92 & ANKRD36 & 90.9 \\
\hline$A C A N$ & 88 & CACNAIB & 90.9 \\
\hline COL4A3 & 88 & CMYA5 & 90.9 \\
\hline DNAH11 & 88 & MKI67 & 90.9 \\
\hline$F C G B P$ & 88 & $O B S C N$ & 90.9 \\
\hline MKI67 & 88 & PLIN4 & 90.9 \\
\hline MUC20 & 88 & PRIM2 & 90.9 \\
\hline PRIM2 & 88 & RNF43 & 90.9 \\
\hline PTCHD3 & 88 & RP1L1 & 90.9 \\
\hline$S C G B 1 C 1$ & 88 & KRT37 & 86.4 \\
\hline ALPK2 & 84 & MUC20 & 86.4 \\
\hline CMYA5 & 84 & NPIPB 15 & 86.4 \\
\hline KRT32 & 84 & $N R A P$ & 86.4 \\
\hline OR $2 B 11$ & 84 & PCNT & 86.4 \\
\hline OR9G1 & 84 & PTPRH & 86.4 \\
\hline PCNT & 84 & $P Z P$ & 86.4 \\
\hline$A L D H 1 B 1$ & 80 & $A C A N$ & 81.8 \\
\hline$A P O B$ & 80 & BPIFB 4 & 81.8 \\
\hline CA6 & 80 & $D R C 7$ & 81.8 \\
\hline
\end{tabular}

samples but only $1 / 22$ homozygous variants were detected in the $16 \mathrm{qN}$ samples (Table 2). Using whole exome analysis, however, $12 / 25$ and 11/22 somatic variants were detected in the two groups respectively, however not all of these were homozygous (or hemizygous in the samples with allelic loss) variants (Supplemental Table 4B).

The 570 variant-containing genes identified in the CilDB and overlapping between tumors with and without 16q abnormalities (Figure 6) were also analyzed using DAVID and GSEA to refine the list of cilia- related genes. Using the functional annotation clustering algorithm in DAVID the most highly enriched annotation cluster included cilia biogenesis, cilium assembly and cilium morphogenesis with an enrichment score of 14.04. Other annotation clusters included with high enrichment scores included cilium movement/primary ciliary dyskinesia $(E R=7.7)$, dynein heavy chain/ axonemal dynein complex $(E R=7.47)$ and intraciliary transport/primary cilium $(E R=3.1)$. Using GSEA on the same 570 overlapping genes (with an FDR q value of $<0.05$ ), 266 genes were identified as belonging to the $\mathrm{GO}$ classifications of $\mathrm{GO}_{-}$ CILIUM , GO CILIUM MORHOGENESIS, GO CILIUM ORGANIZATION, GO CILIARY PART, GO CILIARY PLASMA, GO PRIMARY CILIUM, GO MEMBRANE, GO_AXONEME, GO_ AXONEME ASSEMBLY, GO_CENTROSOME, GO_CENTRIOLE. One hundred and forty-three of the 266 carried variants in at least $25 \%$ of $16 q d e l / L O H$ samples and 149 in $25 \%$ of the tumors without $16 \mathrm{q}$ abnormalities.

\section{Established cilia-dependent pathways}

We next examined well-established, cilia-dependent pathways including Sonic Hedgehog (SHh), Wnt, Plateletderived growth factor receptor (PDGFR), Notch, TGF-B and mTOR for variants in their component molecules. The pathway members and the percentage of samples with variants in tumors with and without $16 \mathrm{q}$ abnormalities are shown in Figure 7.

Although there is a large degree of overlap in the variants for each pathway, some of the genes in each of these pathways differ. For example, in the Wnt Signaling pathway APC, BCL9, KREMEN, c-JUN, FDZ9 and $M D M 2$ variants are evident in the $16 \mathrm{qdel} / \mathrm{LOH}$ samples exclusively and conversely, $A X I N, C D K N 2 A, S O X 7$ and WNT11 are altered solely in the tumors without $16 \mathrm{q}$ abnormalities. The SHh pathway shows larger percentages of somatic variants in the PTCHI and GLI3 genes in the 16qdel/LOH samples, while PIK3R1, ATM and PLD genes are more frequently altered in tumors without $16 \mathrm{q}$ abnormalities. All pathways are shown in Supplemental Image 1 (SI1).Overall, a down-regulation of these pathways due to inactivating somatic variants is predicted.

\section{Variant containing genes previously reported in Wilms tumor}

Genes that have been previously reported to carry variants in Wilms tumors also were found to carry variants in this study, however using our analysis pipeline these 
were not determined to be frequent events. For example, in $A M E R 1$, we detected somatic variants in $6 \%$ of samples, CTNNB1 (0\%), DICER1 (4\%), DGCR8 (6\%), DROSHA (10\%), MLLT1 (16\%), SIX2 (2\%) and TP53 (24\%). The list of the most frequently reported WT-associated variantcontaining genes is shown in Table 4.

\section{DISCUSSION}

Loss of heterozygosity involving distinct regions of chromosome $16 \mathrm{q}$ been extensively correlated with poor outcome in Wilms' tumors and is now included as a test in evaluating therapy options for WT patients. Although the incidence of $16 \mathrm{q}$ loss in WT tends to be $15-20 \%$, [1, $10,14]$ the present study a much higher frequency $(49 \%)$ was observed, most likely due to the TARGET samples being preselected as high-risk, i.e. having either favorable histology (FHWT) that relapsed or DAWT. Wittman et al [15] also reported a higher incidence of $16 \mathrm{q}$ allele loss in mixed-type as well as in diffuse anaplastic tumors, whereas epithelial and stromal tumors rarely exhibited $16 \mathrm{q}$ losses. It was also notable that chromosome 16 loss/ $\mathrm{LOH}$ was a less frequent event in the FHWT class and the majority were classified as DAWT and the number of variant-containing genes mapping to chromosome $16 \mathrm{q}$ was higher in the DAWT as opposed to the FHWT histologically classified samples. It is interesting that Gadd et al. [13] reported a higher percentage of overall variants across the genome in DAWT samples using the TARGET data.

The identification of genes mapping to chromosome $16 \mathrm{q}$ that play a role in WT tumorigenesis have been largely ineffectual and has led to the assumption that more than one gene mapping to this region could attribute to the more aggressive nature of tumors carrying $16 \mathrm{q}$ deletion or $\mathrm{LOH}$. The observation of $\mathrm{LOH}$ is generally taken as being a mechanism of exposing recessive variants in gene critical to tumorigenesis and through our variant profiles focusing on $16 \mathrm{q}$ we found a remarkably consistent incidence of somatic variants in genes related to cilia structure and function. WT is considered an embryonal tumor arrested in early stages of kidney development. An early stage of this process involves the two-way induction of differentiation induced by the contact of the ureteric bud with the metanephric mesenchyme generating waves of differentiation signals as the bud invades the blastemal mass. During this process the kidney goes through differentiation into primitive stages of a pro-nephros and a meso-nephros which are normally degraded to give rise to the metanephric kidney [16]. Importantly, cilia have been shown to play an important role in early stages of this process [17] and ciliary structures can be seen in Wilms tumors reflecting their early stage in developmental arrest [18]. The frequent involvement of somatic variants in genes that are related to cilia, therefore, potentially represents a mechanism of sustaining embryonic status of cells in WT.

The large number of cilia-related genes both mapping to chr16q and containing variants in the 16qdel/ LOH samples aroused our interest in the role of cilia in WT. Specifically we focused on 12 genes that were highly referenced in the literature. Out of $2516 \mathrm{qdel} /$ LOH samples, only 8 did not have variants in ciliarelated genes. Recent studies have shown that hundreds of proteins reside permanently or transiently in cilia. In the kidney, immotile or primary cilia are present on the apical (urinary /luminal) surface of epithelial cells from all tubular segments and are critical sensory and signaling centers. Primary cilia are solitary and immotile cellular appendages that serve as signaling hubs for many signaling pathways during development (see below). Defects in their structure/function result in a spectrum of clinical and developmental pathologies.

Some of the genes that were detected through our analysis are related to motile cilia components and would not impact the primary or non-motile renal cilium, however it should be kept in mind that these tumors arise in the developing kidney and are blastemal in nature. Furthermore, the role of motile cilia in nephrogenesis has not been elucidated, for example, multi-ciliated cells, or cells that contain multiple motile cilia have been reported in fetal kidney tubules [19] and sporadically in an assortment of renal diseases [20, 21]. Additionally, despite the distinction between primary and motile cilia, it

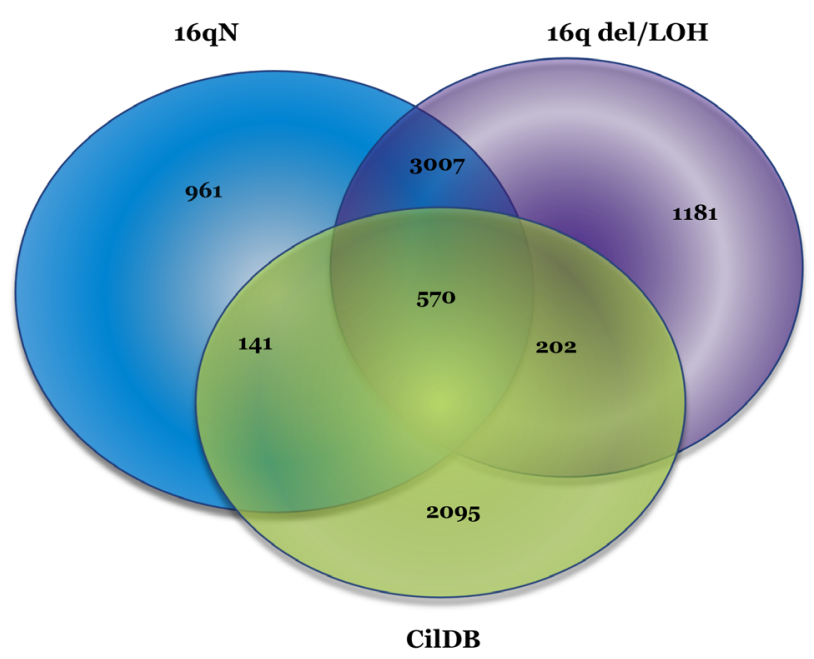

Figure 6: Venn Diagram of Variant-containing Genes in CilDB. Genes that are listed in the CilDB (3008 human genes) are shown in green, the $16 \mathrm{qN}$ samples (4679 genes) in blue and the 16qldel/LOH samples (4960 genes) shown in red. The number of genes overlapping between $16 \mathrm{qdel} / \mathrm{LOH}$ samples and the CiliaDB is higher than the number overlapping between the 16qN samples and the CiliaDB. The gene lists for each of these categories is available in Supplemental Table 4A. 


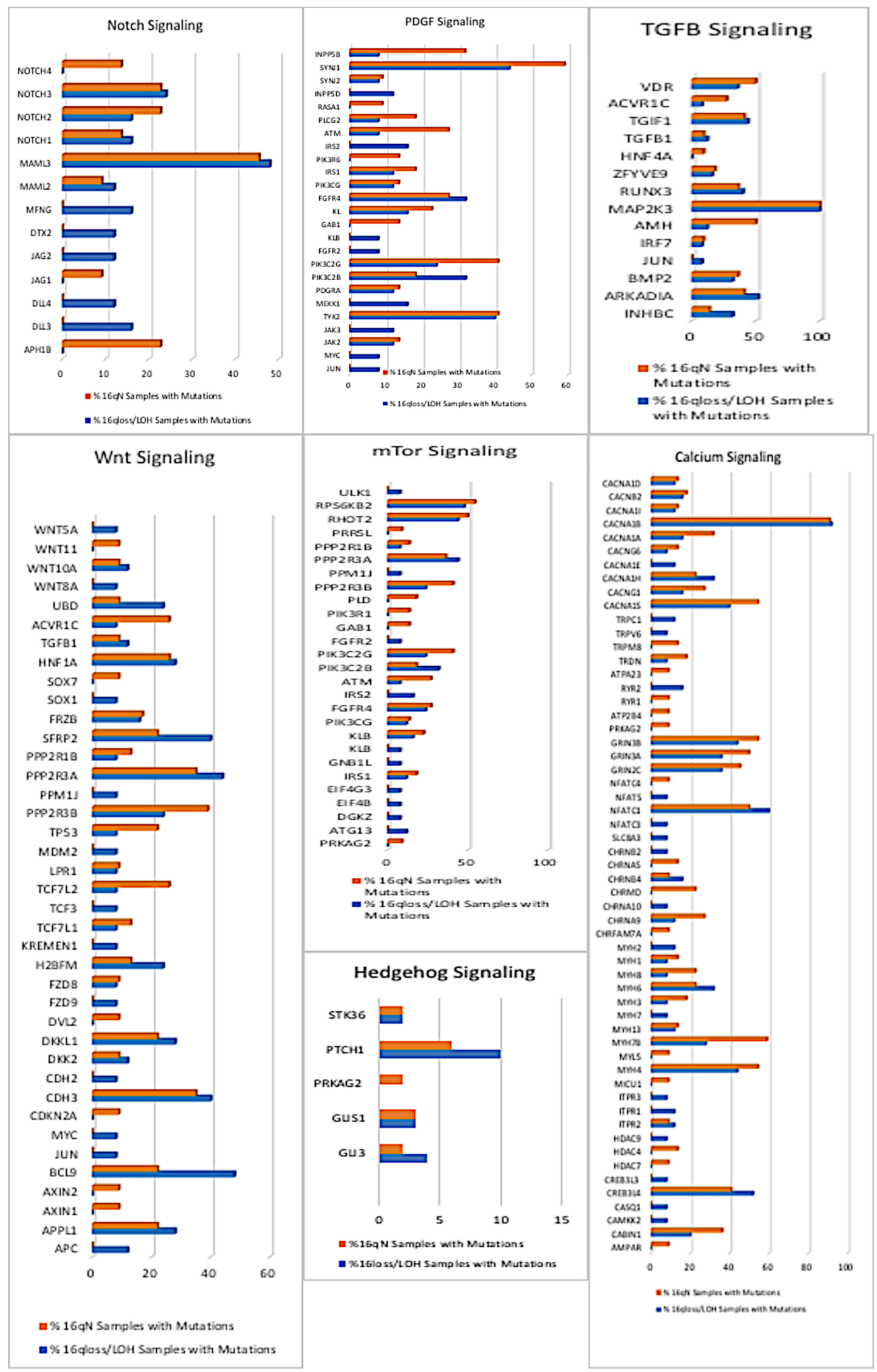

Figure 7: Deleterious Variants in Cilia-Related Pathways. The X-axis of each bar chart shows the names of the genes in each pathway that carry mutations. The y axes show the number of mutations in each of the genes. The orange bars represent the 16q- samples and the blue bars represent the number of mutations in the $16 \mathrm{q}+$ samples. 
Table 4: List of Genes with Reported Mutations in Wilms Tumors. The table lists genes that have previously reported to carry mutations in Wilms tumors. The sample number heading refers to the number of samples with somatic variants detected in the gene out of a possible 50 total. The percentage heading is the percentage of 50 samples with the somatic variants. Starred genes refer to the genes reported by Gadd et al using the Target Database samples.

\begin{tabular}{|c|c|c|}
\hline Gene & Sample \# & $\%$ in 50 samples \\
\hline AMERI & 3 & 6.0 \\
\hline CTNNB1 & 0 & 0.0 \\
\hline$D G C R 8$ & 3 & 6.0 \\
\hline DICERI & 2 & 4.0 \\
\hline DROSHA & 5 & 10.0 \\
\hline$M L L T 1$ & 8 & 16.0 \\
\hline$M Y C N$ & 0 & 0.0 \\
\hline$S I X 1$ & 1 & 2.0 \\
\hline SIX2 & 1 & 2.0 \\
\hline TP53 & 12 & 24.0 \\
\hline$W T 1$ & 2 & 4.0 \\
\hline XPO5 & 3 & 6.0 \\
\hline ARID1A* & 1 & 2.0 \\
\hline$A S X L 1 *$ & 4 & 8.0 \\
\hline$B C O R^{*}$ & 0 & 0.0 \\
\hline BCORL1* & 0 & 0.0 \\
\hline COL6A3* & 0 & 0.0 \\
\hline$M A P 3 K 4^{*}$ & 5 & 10.0 \\
\hline$M A X^{*}$ & 0 & 0.0 \\
\hline NONO* & 0 & 0.0 \\
\hline
\end{tabular}

* genes reported by Gadd et al. 2017

has been reported that there is a clinical overlap between Primary Ciliary Dyskinesia (PCD) and many of the nonmotile-ciliopathies [22].

The most frequently altered gene detected in the present study was $D R C 7$ (dyenin regulatory complex 7) a misnomer as this is a conserved ciliary protein localized to the outer microtubule doublets of the axoneme and is not associated with the dynein arms [23]. The role of this protein localizing to the axoneme implies that it may also be involved in primary cilia function, and play a role in nephrogenesis.

Several of the detected somatic variants mapping to $16 \mathrm{q}$ are involved in PCD a rare genetic disease that is inherited as an autosomal-recessive trait. For example, HYDIN was frequently found to carry variants in patients with chromosome $16 \mathrm{q} \mathrm{del} / \mathrm{LOH}$. This gene encodes a protein that is integral to the central pair apparatus of motile cilia. Raidt et al [24] examined ciliary beat patterns for PCD patients carrying different somatic variants and reported that many of the cilia in nasal brushings of HYDIN mutation carriers were actually primary/immotile cilia, suggesting that the classification of these two subtypes of cilia is not definitive.

Another frequently altered gene was NQO1, a gene which has been reported as down-regulated in PCD biopsies of lung [25] and reduced expression leads to increased kidney injury in response to cisplatin [26].

$G A S 8$, another PCD-related gene, encodes a subunit of the nexin-dynein regulatory complex and connects microtubule doublets. GAS8 variants are associated with axonemal disorganization sometimes characterized by a partial loss of inner dynein arms [27, 28]. Interestingly, although GAS8 localized to the microtubule axoneme of motile cilia it also localized to the base of non-motile/ primary cilia [29] and the role in non-motile cilia has not been elucidated. Intriguingly, GAS 8 plays a role in the SHh signaling pathway. Evron et al [30] have shown in a murine model that Gas8 binds to Smoothened (Smo) and acts at the base of primary cilia as a regulator of Smo entry into the cilium following SHh pathway activation. In the absence of Gas8, Smo accumulation in the cilium is abrogated and that it cannot activate the Gli transcription factors that ultimately govern the expression of downstream genes.

The transition zone (TZ) is the proximal-most domain of the ciliary axoneme, found immediately distal to the basal body and is critical to cilium formation and functions as a portal that maintains the correct composition of the ciliary organelle. Variants in genes that affect TZ function result in wide range of ciliopathies. TMEM231 is mandatory for the localization of a subset of the MKS complex components to the $\mathrm{TZ}$ and to maintain ciliary protein composition. Another TZ protein, RPGRIP1L is also mutated in Merkel Syndrome (MKS) which is characterized by kidney cysts. Furthermore, variants in this gene cause Nephronophthisis (NPHP) which also characterized by kidney cysts. Genetic disruption of the transition zone disorders the ciliary localization of membrane-associated proteins including SHh-related $S M O$ that requires the transition-zone proteins including TMEM231 to accumulate within the ciliary membrane. Consequently, loss of any of these proteins leads to SHhassociated developmental defects [31].

Whole exome analysis also revealed that a large percentage of genes associated with ciliogenesis and mitosis carried somatic variants in both $16 \mathrm{qN}$ and $16 \mathrm{qdel} / \mathrm{LOH}$ samples. Given that WT is a developmental tumor, these findings are notable. Although not reported specifically for Wilms tumor, an ever-increasing number of papers report on a decrease, loss, or distortion of the primary cilium in a variety of cancer types. It is commonly assumed that the cilium act as to control 
cellular proliferation by employing the same structural components required for chromosome segregation [32]. Loss of the cilium in cancer cells may, therefore, result in loss of these components and contribute to distorted cellular signaling [33]. Additionally, given the critical role of cilium in cell division, defects in cilia- related genes have become a viable explanation for ciliopathy phenotypes that appear during development as many cells are actively proliferating during this phase and therefore do not have cilia [34].

Further analysis of the established cilia-related pathways revealed that a large number of genes in these pathways carried somatic variants in the WT samples. The SHh was discussed above in the context of $16 \mathrm{qdel} / \mathrm{LOH}$ homozygous variants detected in the GAS8 and TMEM231 genes. The SHh signaling plays an essential role in many aspects of embryonic development and tumorigenesis. The cilium functions as the transduction hub for $\mathrm{SHh}$ signaling [35]. Our analysis found $34 \%$ of samples carried PTCH1 somatic variants and somatic variants of GLI3, GLIS1 STK3 and PRKAG2 were also detected. Variants in $P T C H 1$ are associated with rhabdomyosarcoma [36], other studies report increased expression of $\mathrm{PTCH} 1$ in pediatric solid tumors including Wilms tumor [37].

Many parallel and divergent lines of evidence point to Wnt Signaling (both canonical and non-canonical) as central pathways in nephrogenesis. The Wnt/ $\beta$-catenin pathway is one of the multiple signaling pathways that cooperate in the initiation and progression of mesenchymal-epithelial transition and several members of the Wnt family have been implicated in the induction of epithelial renal vesicles (See 38 review). Wilms tumor development is tightly linked to nephron genesis and are frequently found within nephrogenic nests that resemble embryonic structures suggesting a block in the nephrogenic process by variants in the Wnt Signaling members. We report a large number of genes involved Wnt Signaling are altered in the WT cohort examined. The cilia and basal body function as regulatory mechanisms to govern Wnt signaling and signaling is mediated in the primary cilia. Additionally, ciliary-related proteins have been also shown to regulate Wnt signaling pathways.

Notch signaling also plays an elemental role in mammalian nephrogenesis. The differentiation of nephron progenitors requires the down-regulation of SIX2 and this accomplished by the Notch Signaling pathway [39]. Notch also regulates the process of nephron segmentation involving the differentiation of progenitor cells into the renal corpuscle, proximal tubule, loop of Henle and distal tubule [40]. Cells lacking the Notch signaling pathway fail to form these structures reminiscent of the disorganized nephrons typically observed in WT. The Notch signaling pathway plays a central role in left right symmetry and cilium length control. Our analysis revealed somatic variants in all 4 Notch receptors, with $23 \%$ of samples carrying somatic variants in NOTCH3.
The plethora of events, both in normal and disease states, involving calcium signaling is overwhelming, however studies of the role of calcium in kidney development has historically been largely overlooked. $P K D 1$ and $P K D 2$ encode proteins that interact to form a calcium permeable channel in response to mechanosensory stimuli in ciliary membrane and this channel becomes dysfunctional due to variants in PKD patients. Other interacting members of PKD2, TRPC1 and TRPV4 show strong expression patterns in the embryonic proximal tubules and ureteric bud and genes carried somatic variants in our cohort. Additionally, calcium entry in response to extracellular stimuli results in calcineurin (PPP $3 C A)$ activation, and signal transduction from the cytoplasm into the nucleus through dephosphorylation and nuclear translocation of the transcription factor nuclear factor of activated $\mathrm{T}$ cells (NFAT). This initiates a cascade of transcriptional events involved in physiological and developmental processes [41]. We detected a large number of variants in members of the NFAT family with $55 \%$ of patients carrying somatic variants in NFAT1. Notably, $C A B I N 1$, a calcineurin binding protein which results in decreased $P P P C 3 A$ expression is highly expressed in mesenchymal progenitor cells at the onset of metanephric kidney development has been found to be over-expressed in WT [42]. In the present study, we detected CABIN1 somatic variants in $28 \%$ of samples assayed.

Other established cilia-related pathways are less documented in terms of nephrogenesis or WT. Notwithstanding, the mTOR signaling pathway is mediated by the primary cilia and inappropriately activated in cyst-lining epithelial cells in human $A D P K D$ patients and mouse models [43]. Defects in the autophagy pathway have been detected in PKD and ciliopathies display impaired autophagy [44]. TGF $\beta$ and PDGF signaling are intricately involved in the development of renal fibrosis [45].

Whole exome analysis concurred with similar studies using the target dataset with some major differences. The most frequently altered genes in our study did not correspond to those reported by Gadd et al [13]. This was primarily due to differences in data filtering for instance, their discovery set was limited to variants reported in COSMIC including nonsense, and frameshift variants and verified somatic missense and in-frame variants predicted to be damaging and not identified in 1000 Genomes series 3. We did not filter our data using these criteria but relied on detecting somatic variants that were tumor specific. As a result, our somatic variant list is much more extensive and we detected many genes that were altered in a large percentage of samples, however our sample size is smaller.

TP53 was the most commonly mutated gene in a study reported by GADD et al [13] using their discovery set analysis, the mutation rate was $22 \%$ and using our analysis, we calculated the variant-containing rate as $26 \%$ 
(Table 4). Similarly, we found our variant-containing rates concurred with those reported by Gadd et al for most of the WT-related genes except for CTNNB1, a gene reported by Gadd et al, as the second most frequently variantcontaining gene whereas we detected no variants using our analysis pipeline. Presumably, the predictions for the effects of somatic variants by PolyPhen and SIFT were finally selected to be damaging and/or deleterious in our study.

\section{MATERIALS AND METHODS}

\section{Copy number analysis}

We have previously performed copy number analysis for the 8 legacy Wilms tumor samples reported by Cowell and Hawthorn [10]. The TARGET samples were analyzed using Partek Genomics Suite 6.6 (Partek Inc., St Louis, MO, USA) for LOH and copy number alterations (CNAs) using paired .CEL and .CHP files, which were generated using Genome-Wide Human 6.0 SNP arrays (Affymetrix), from the TARGET database. For CNA analysis, the genomic segmentation algorithm available in Partek Genomics Suite was employed using default parameters, including minimum genomics markers: 50, signal to noise ratio: 0.3 , segmentation p-value: 0.01 . LOH was analyzed using the Hidden Markov model (HMM) algorithm with default parameters, max probability: 0.9999 and genotype error: 0.01 .

\section{DNA samples for exome sequencing}

Genomic DNAs were prepared from 8 WT tissues (GOS100, 11, 132, 32, 52, 54, 576, 900), using standard phenol/chloroform extraction procedures or Wizard Genomics DNA purification kits (Madison, WI). Tumor samples were collected immediately following surgical resection during the period 1982-1992 and snap frozen in liquid nitrogen. At the time of collection, the diagnosis of WT was confirmed histopathologically, although in some cases the specific stage was not recorded. Unfortunately, it has also not been possible to recover this information retrospectively from some of the anonymized legacy samples. DNA was prepared from the whole tumor sample from snap frozen tissue using standard phenol/chloroform extraction procedures. Supplemental Table S1 shows the clinical information available for each sample used in the study and specifies which analyses were performed on the individual samples.

\section{Exome sequencing}

Exon capture libraries were constructed from $1 \mathrm{ug}$ of genomic DNA using the Agilent Human All Exon Target Enrichment kit $(38 \mathrm{Mb})$ or the SureSelect Human All Exon $50 \mathrm{Mb}$ kit according to the manufacturer's protocol (Agilent, Santa Clara, CA). The individual libraries were quality-checked and quantified using the Agilent 2100 Bioanalyzer and SYBR Green-qPCR (BIO-RAD, Hercules, CA), respectively. The libraries were sequenced on the Illumina HiSeq 2500 ver. 2 (Illumina, San Diego, CA) using paired-end, 50 bp cycles. Base calling, reads quality assessment, de-multiplexing, and transferring to a fastq format was performed using Illumina data analysis software. FastQC was used for Quality control of the sequence reads. The average number of reads was $50 \mathrm{million} / \mathrm{sample}$ and on average, $92 \%$ of total reads uniquely mapped on the $\mathrm{NCBI} 37 / \mathrm{hg} 19$ reference sequence.

\section{Exome data analysis}

Reads that passed quality control were then aligned to the human reference genome (hg19) using BWA (Burrow-Wheelers Aligner version 0.6.1) with default settings. The generated BAM files were imported into Genome Analysis Toolkit, GATK2, for removal of duplicates, local realignment, mate-pair fixation, re-calibration and then variants were detected by HaplotypeCaller with a cutoff of depth at least 5. Germline variants were excluded by subtracting normal genotypes from tumor profiles using bedtools. In the case of our 8 legacy samples, we had lymphblastoid cell lines from 3 patients, for the remaining 5 patients we used the pooled lymphoblastoid cell line data as a baseline. The somatic variants resulting from these analyses were annotated using Ensemble variant effect predictor, VEP (release ver. 75). In the same way, 42 matched tumor-normal WTs, available through the TARGET study, were analyzed to search for somatic variants on chr16q. These annotated data were then filtered to investigate only those variants that were predicted to cause protein dysfunction and included deletions and insertions that lead to frame shifts, variants in critical splice junction nucleotides and missense variants generating stop codons or leading to predicted deleterious events in the protein. SIFT (Sort Intolerant From Tolerant) [11] and/ or PolyPhen-2 (Polymorphism Phenotyping v.2.) [12] were used to annotate the damaging and deleterious effects of missense variants.

For analysis of $16 \mathrm{q}$ specific somatic alterations, the data were filtered to include only altered alleles on chr16q. The annotated variants from exome data were categorized according to the chr16q structural abnormalities as determined by microarray analysis resulting in 25 WTs with16qdel/LOH and 22 WTs with wild-type chr16q 
profiles $(16 \mathrm{qN})$. For $16 \mathrm{qdel} / \mathrm{LOH}$ samples, variants caused by deletion were sorted according to the ratio of read depths between a reference and an altered allele for each position and filtered to include variants with $>=80 \%$ of altered allele ratio in tumor samples and $<=75 \%$ in the matched control samples with consideration for normal tissue contamination.

Several pathway analysis programs were used to analyze the data, including Ingenuity Pathway Analysis (IPA, http://www.qiagenbioinformatics.com), Database for Annotation, Visualization and Integrated Discovery (DAVID v6.8. https://david.ncifcrf.gov/home.jsp), Geneset Enrichment Analysis (GSEA, http://software. broadinstitute.org $/ \mathrm{gsea} / \mathrm{msigdb} / \mathrm{annotate} . \mathrm{jsp}$ ). Analysis of cilia-related gene overlaps was conducted using CilDB (http://cildb.cgm.cnrs-gif.fr). For DAVID, a Fisher Exact $\mathrm{P}$-Value is used to determine whether the proportion of genes falling into each category differs by group. The Fisher Exact is adopted to measure gene enrichment in annotation terms. We have reported Enrichment scores for each of the Functional Annotation clusters which is based on the p-values for each of the term members. An FDR q-value $=0.05$ was used to compute overlaps in GSEA Hallmark Genesets.

\section{CONCLUSION}

In summary, we have found that $49 \%$ of WT samples carry a del/LOH event on chromosome 16q when the patient cohort is preselected as high risk. These findings support a number of other studies implicating structural abnormalities of $16 \mathrm{q}$ with more aggressive form of WT. Studies aimed at identifying causative genes in minimal regions of overlap in patients with del/ $\mathrm{LOH}$ at 16q have been largely unsuccessful and this may be due to multiple gene variants mapping to that region of the genome. We have identified a series of WT samples with chromosome16q del/LOH and defined deleterious variants in genes mapping to that region. We propose that increased ciliary dysfunction may be responsible of the more aggressive nature of WT with chromosome 16q del/ LOH.

\section{ABBREVIATIONS}

\begin{tabular}{|l|l|}
\hline Acronym & Description \\
\hline $16 \mathrm{~N}$ & tumors with no loss of 16q \\
\hline $16 \mathrm{qdel} / \mathrm{LOH}$ & $\begin{array}{l}\text { Tumors with deletion or } \\
\text { LOH of 16q }\end{array}$ \\
\hline ABCC12 & $\begin{array}{l}\text { ATP-binding cassette, sub- } \\
\text { family C (CFTR/MRP), } \\
\text { member 12 }\end{array}$ \\
\hline ACAN & aggrecan \\
\hline ACSF3 & $\begin{array}{l}\text { acyl-CoA synthetase family } \\
\text { member 3 }\end{array}$ \\
\hline
\end{tabular}

\begin{tabular}{|c|c|}
\hline ADAMTS18 & $\begin{array}{l}\text { DAM metallopeptidase } \\
\text { with thrombospondin type } \\
1 \text { motif, } 18\end{array}$ \\
\hline ADPKD & $\begin{array}{l}\text { Autosomal Dominant } \\
\text { Polycystic Kidney Disease }\end{array}$ \\
\hline ALDH1B1 & $\begin{array}{l}\text { aldehyde dehydrogenase } 1 \\
\text { family, member B1 }\end{array}$ \\
\hline ALPK2 & alpha-kinase 2 \\
\hline AMER1 & $\begin{array}{l}\text { APC } \\
\text { recruitment protein } 1\end{array}$ \\
\hline ANKRD36 & ankyrin repeat domain 36 \\
\hline APC & $\begin{array}{ll}\text { Adenomatous polyposis } \\
\text { coli }\end{array}$ \\
\hline APOB & apolipoprotein B \\
\hline ARID1A & $\begin{array}{l}\text { AT rich interactive domain } \\
1 \mathrm{~A}\end{array}$ \\
\hline ASXL1 & additional sex combs like 1 \\
\hline ATM & $\begin{array}{ll}\text { ataxia } & \text { telangiectasia } \\
\text { mutated } & \\
\end{array}$ \\
\hline AXIN & Axis Inhibition Protein \\
\hline BCL-9 & B-Cell Lymphoma-9 \\
\hline BCLAF1 & $\begin{array}{l}\text { BCL2-associated } \\
\text { transcription factor } 1\end{array}$ \\
\hline BCMO1 & $\begin{array}{l}\text { beta-carotene } \\
15,15 \text { '-monooxygenase } 1\end{array}$ \\
\hline $\mathrm{BCOR}$ & BCL6 Corepressor \\
\hline BCORL1 & BCL6 Corepressor Like 1 \\
\hline BPIFB4 & $\begin{array}{l}\text { BPI fold containing family } \\
\text { B, member } 4\end{array}$ \\
\hline BWA & Burrow-Wheelers Aligner \\
\hline c-JUN & Jun Oncogene \\
\hline CA6 & carbonic anhydrase VI \\
\hline CABIN1 & $\begin{array}{l}\text { calcineurin binding protein } \\
1\end{array}$ \\
\hline CACNA1B & $\begin{array}{l}\text { calcium channel, voltage- } \\
\text { dependent, } N \text { type, alpha } \\
\text { 1B subunit }\end{array}$ \\
\hline CCDC135 & $\begin{array}{ll}\text { coiled-coil } & \text { domain } \\
\text { containing 135 } & \\
\end{array}$ \\
\hline CDH11 & cadherin 11 \\
\hline $\mathrm{CDH} 3$ & cadherin 3 \\
\hline CDKN2A & $\begin{array}{ll}\text { cyclin-dependent } & \text { kinase } \\
\text { inhibitor 2A } & \\
\end{array}$ \\
\hline CES1 & carboxylesterase 1 \\
\hline CHST5 & $\begin{array}{l}\text { carbohydrate } \\
\text { (N-acetylglucosamine 6-O) } \\
\text { sulfotransferase } 5\end{array}$ \\
\hline CMYA5 & $\begin{array}{l}\text { cardiomyopathy associated } \\
5\end{array}$ \\
\hline $\mathrm{CNA}$ & Copy Number Alteration \\
\hline CNGB1 & $\begin{array}{l}\text { cyclic nucleotide gated } \\
\text { channel beta } 1\end{array}$ \\
\hline COL4A3 & collagen, type IV, alpha 3 \\
\hline COL6A3 & $\begin{array}{l}\text { Collagen Type VI Alpha } 3 \\
\text { Chain }\end{array}$ \\
\hline CTNNB1 & $\begin{array}{ll}\text { catenin } & \text { (cadherin- } \\
\text { associated protein), beta } 1\end{array}$ \\
\hline
\end{tabular}




\begin{tabular}{|c|c|}
\hline CTU2 & $\begin{array}{l}\text { cytosolic thiouridylase } \\
\text { subunit } 2 \text { homolog }\end{array}$ \\
\hline DAVID & $\begin{array}{l}\text { Database for Annotation, } \\
\text { Visualization } \\
\text { Integrated Discovery }\end{array}$ \\
\hline DAWT & $\begin{array}{l}\text { Diffuse Anaplastic Wilms } \\
\text { Tumor }\end{array}$ \\
\hline del & deletion \\
\hline DGCR8 & $\begin{array}{l}\text { DGCR8 microprocessor } \\
\text { complex subunit }\end{array}$ \\
\hline DICER1 & $\begin{array}{l}\text { dicer } 1 \text {, ribonuclease type } \\
\text { III }\end{array}$ \\
\hline DNA & Deoxyribonucleic Acid \\
\hline DNAH11 & $\begin{array}{l}\text { dynein, axonemal, heavy } \\
\text { chain 11 }\end{array}$ \\
\hline DNAH5 & $\begin{array}{l}\text { dynein, axonemal, heavy } \\
\text { chain 5 }\end{array}$ \\
\hline DRC7 & $\begin{array}{l}\text { dyenin regulatory complex } \\
7\end{array}$ \\
\hline DROSHA & $\begin{array}{l}\text { drosha, ribonuclease type } \\
\text { III }\end{array}$ \\
\hline ENKD1 & $\begin{array}{l}\text { enkurin domain containing } \\
1\end{array}$ \\
\hline FCGBP & $\begin{array}{l}\text { Fc fragment of IgG binding } \\
\text { protein }\end{array}$ \\
\hline FDZ9 & Fizzled 9 \\
\hline FHWT & $\begin{array}{l}\text { Favorable Histology Wilms } \\
\text { Tumor }\end{array}$ \\
\hline GAS8 & growth arrest-specific 8 \\
\hline GATK & Genome Analysis Toolkit \\
\hline GLI3 & GLI family zinc finger 3 \\
\hline GLIS1 & GLIS family zinc finger 1 \\
\hline GPR98 & $\begin{array}{l}\text { G protein-coupled receptor } \\
98\end{array}$ \\
\hline GPRIN2 & $\begin{array}{l}\text { G protein regulated inducer } \\
\text { of neurite outgrowth } 2\end{array}$ \\
\hline GSEA & $\begin{array}{|ll|}\text { Geneset } & \text { Enrichment } \\
\text { Analysis } & \\
\end{array}$ \\
\hline HMM & Hidden Markov Model \\
\hline HSD17B2 & \begin{tabular}{|l} 
hydroxysteroid (17-beta) \\
dehydrogenase 2
\end{tabular} \\
\hline HYDIN & \begin{tabular}{|lc}
$\begin{array}{l}\text { axonemal central pair } \\
\text { apparatus protein }\end{array}$ & pal \\
\end{tabular} \\
\hline IPA & \begin{tabular}{|ll}
$\begin{array}{l}\text { Ingenuity } \\
\text { Analysis }\end{array}$ & Pathway \\
\end{tabular} \\
\hline KCNG4 & \begin{tabular}{|l} 
potassium \\
channel, \\
member 4
\end{tabular} \\
\hline KCNJ12 & \begin{tabular}{|lr} 
potassium & inwardly- \\
rectifying & channel, \\
subfamily J, member 12
\end{tabular} \\
\hline KREMEN & $\begin{array}{l}\text { Kringle domain-containing } \\
\text { transmembrane protein }\end{array}$ \\
\hline KRT32 & keratin 32 \\
\hline KRT32 & keratin 32 \\
\hline KRT37 & keratin 37 \\
\hline $\mathrm{LOH}$ & Loss of Heterozygosity \\
\hline
\end{tabular}

\begin{tabular}{|c|c|}
\hline MAP2K3 & $\begin{array}{l}\text { mitogen-activated protein } \\
\text { kinase kinase } 3\end{array}$ \\
\hline MAP3K4 & $\begin{array}{l}\text { Mitogen-Activated Protein } \\
\text { Kinase Kinase Kinase } 4\end{array}$ \\
\hline MAX & MYC Associated Factor X \\
\hline MC1R & melanocortin 1 receptor \\
\hline MDM2 & Mouse Double Minute 2 \\
\hline MKI67 & \begin{tabular}{|l} 
marker of proliferation Ki- \\
67
\end{tabular} \\
\hline MKS & Merkel Syndrome \\
\hline MLLT1 & $\begin{array}{|lr|}\text { mixed-lineage } & \text { leukemia } \\
\text { (trithorax } & \text { homolog, } \\
\text { Drosophila); } & \text { translocated } \\
\text { to, } 1 & \\
\end{array}$ \\
\hline MT1A & metallothionein 1A \\
\hline mTOR & \begin{tabular}{|lcc}
$\begin{array}{l}\text { mammalian } \\
\text { Rapamycin }\end{array}$ & Target of \\
\end{tabular} \\
\hline MUC20 & \begin{tabular}{|l}
$\begin{array}{l}\text { mucin 20, cell surface } \\
\text { associated }\end{array}$ \\
\end{tabular} \\
\hline MUC3A & mucin 3A \\
\hline MYCN & \begin{tabular}{|lr}
$\mathrm{v}$-myc & avian \\
myelocytomatosis & viral \\
oncogene neuroblastoma \\
derived homolog
\end{tabular} \\
\hline NEB & nebulin \\
\hline NFAT & $\begin{array}{l}\text { nuclear factor of activated } \\
\text { T-cells }\end{array}$ \\
\hline NONO & $\begin{array}{|ll|}\begin{array}{l}\text { Non-POU } \\
\text { Containing }\end{array} & \text { Domain } \\
\text { Binding } & \text { Octamer } \\
\end{array}$ \\
\hline NPHP & Nephronophthisis \\
\hline NPIPB15 & $\begin{array}{l}\text { nuclear pore complex } \\
\text { interacting protein family, } \\
\text { member B15 }\end{array}$ \\
\hline NQO1 & $\begin{array}{l}\text { NAD(P)H dehydrogenase, } \\
\text { quinone } 1\end{array}$ \\
\hline NRAP & $\begin{array}{l}\text { nebulin-related anchoring } \\
\text { protein }\end{array}$ \\
\hline NRAP & $\begin{array}{l}\begin{array}{l}\text { nebulin-related anchoring } \\
\text { protei }\end{array} \\
\end{array}$ \\
\hline NWTSG & \begin{tabular}{|l}
$\begin{array}{l}\text { National Wilms' Tumor } \\
\text { Study Group }\end{array}$ \\
\end{tabular} \\
\hline OBSCN & obscurin, \\
\hline OR2B11 & $\begin{array}{l}\text { olfactory receptor, family } \\
2 \text {, subfamily B, member } 11 \\
\end{array}$ \\
\hline OR4C3 & $\begin{array}{l}\text { olfactory receptor, family } \\
4, \text { subfamily C, member } 3 \\
\end{array}$ \\
\hline OR9G1 & $\begin{array}{l}\text { olfactory receptor, family } \\
9, \text { subfamily G, member } 1\end{array}$ \\
\hline PCD & Primary Ciliary Dyskinesia \\
\hline PCNT & pericentrin \\
\hline PDE4DIP & \begin{tabular}{|ll} 
phosphodiesterase \\
interacting protein
\end{tabular} \\
\hline PDGFR & $\begin{array}{l}\text { Platelet-derived growth } \\
\text { factor }\end{array}$ \\
\hline PHLPP2 & $\begin{array}{l}\text { PH domain and leucine rich } \\
\text { repeat protein phosphatase } \\
2\end{array}$ \\
\hline
\end{tabular}




\begin{tabular}{|c|c|}
\hline PIK3R1 & $\begin{array}{l}\text { phosphoinositide-3-kinase, } \\
\text { regulatory subunit } 1 \text { (alpha) }\end{array}$ \\
\hline PKD & Polycystic Kidney Disease \\
\hline \begin{tabular}{|l|} 
PKD1 \\
\end{tabular} & polycystic kidney disease 1 \\
\hline PKD1L2 & $\begin{array}{l}\text { polycystic kidney disease } \\
\text { 1-like } 2\end{array}$ \\
\hline PKD2 & polycystic kidney disease 2 \\
\hline PLD & phospholipase D family, \\
\hline PLIN4 & perilipin 4 \\
\hline PMFBP1 & $\begin{array}{l}\text { polyamine modulated } \\
\text { factor } 1 \text { binding protein } 1\end{array}$ \\
\hline POLYPHEN & \begin{tabular}{|l|} 
Polymorphism \\
Phenotyping
\end{tabular} \\
\hline PPP3CA & \begin{tabular}{|l} 
protein phosphatase 3, \\
catalytic \\
isozyme
\end{tabular} \\
\hline PRIM2 & $\begin{array}{l}\text { primase, DNA, polypeptide } \\
2\end{array}$ \\
\hline PRKAG2 & \begin{tabular}{|l}
$\begin{array}{l}\text { protein kinase, } \\
\text { activated, gamma } \\
\text { catalytic subunit }\end{array}$ \\
non- \\
\end{tabular} \\
\hline PTCH1 & Patched 1 \\
\hline PTCHD3 & \begin{tabular}{|l} 
patched domain containing \\
3
\end{tabular} \\
\hline PTPRH & \begin{tabular}{|lr} 
protein tyrosine \\
phosphatase, receptor type, \\
H
\end{tabular} \\
\hline $\mathrm{PZP}$ & pregnancy-zone protein \\
\hline RHBG & Rh family, B glycoprotein \\
\hline RNF43 & ring finger protein 43 \\
\hline RP1L1 & \begin{tabular}{|l} 
retinitis pigmentosa 1-like \\
1
\end{tabular} \\
\hline RPGRIP1L & $\begin{array}{|lc|}\text { retinitis } & \text { pigmentosa } \\
\text { GTPase } & \text { regulator } \\
\text { interacting protein 1 like } \\
\end{array}$ \\
\hline SCGB1C1 & $\begin{array}{l}\text { secretoglobin, family } 1 \mathrm{C} \text {, } \\
\text { member } 1\end{array}$ \\
\hline SHh & Sonic Hedgehog \\
\hline SIFT & \begin{tabular}{|ll}
$\begin{array}{l}\text { Sort Intolerant } \\
\text { Tolerant }\end{array}$ & From \\
\end{tabular} \\
\hline SIX1 & SIX homeobox 1 \\
\hline SIX2 & SIX homeobox 2 \\
\hline SMO & $\begin{array}{l}\text { smoothened, frizzled class } \\
\text { receptor }\end{array}$ \\
\hline SNP & \begin{tabular}{|l|l|}
$\begin{array}{l}\text { Single } \\
\text { Polymorphism }\end{array}$ \\
\end{tabular} \\
\hline SOX7 & $\begin{array}{l}\text { SRY (sex determining } \\
\text { region Y)-box } 7\end{array}$ \\
\hline STK3 & serine/threonine kinase 3 \\
\hline TAF1C & $\begin{array}{l}\text { TATA box binding protein } \\
\text { (TBP)-associated factor }\end{array}$ \\
\hline TARGET & $\begin{array}{l}\text { Therapeutically Applicable } \\
\text { Research to Generate } \\
\text { Effective Treatments }\end{array}$ \\
\hline TGF-B & $\begin{array}{|ll|}\text { Transforming } \\
\text { Factor-Beta }\end{array}$ \\
\hline TMEM231 & transmembrane protein 231 \\
\hline
\end{tabular}

\begin{tabular}{|l|l|}
\hline TP53 & tumor protein p53 \\
\hline TRPC1 & $\begin{array}{l}\text { transient receptor potential } \\
\text { cation channel, subfamily } \\
\text { C, member 1 }\end{array}$ \\
\hline TRPV4 & $\begin{array}{l}\text { transient receptor potential } \\
\text { cation channel, subfamily } \\
\text { V, member 4 }\end{array}$ \\
\hline TUBB3 & tubulin, beta 3 class III \\
\hline TZ & Transition Zone \\
\hline UKCCSG & $\begin{array}{l}\text { United Kingdom Children's } \\
\text { Cancer Study Group }\end{array}$ \\
\hline VEP & Variant Effects Predictor \\
\hline Wnt & Wingless/Integrated \\
\hline WNT11 & $\begin{array}{l}\text { wingless-type } \\
\text { integration site family, } \\
\text { member 11 }\end{array}$ \\
\hline WT & Wilms Tumor \\
\hline WT1 & Wilms tumor 1 \\
\hline XPO5 & exportin 5 \\
\hline ZCCHC14 & $\begin{array}{l}\text { zinc finger, CCHC domain } \\
\text { containing 14 }\end{array}$ \\
\hline ZNF19 & zinc finger protein 19 \\
\hline ZNF778 & zinc finger protein 778 \\
\hline
\end{tabular}

\section{AUTHOR CONTRIBUTIONS}

E.K. was responsible for conducting the sequencing experiments and analysis of the microarray data to identify chromosome 16qloss/LOH samples. C-S. C. performed the bioinformatics analysis of the exome data, identified variants and performed analysis of the effects of the variants at the protein level. J.K.C. acted as an advisor as an expert in the field, provided samples and proof read the manuscript. L.H. designed the experiments, obtained the TARGET data, analyzed the pathways and wrote the manuscript.

\section{CONFLICT OF INTEREST}

There is no conflict of interests.

\section{REFERENCES}

1. Deng C, Dai R, Li X, Liu F. Genetic variation frequencies in Wilms' tumor: A meta-analysis and systematic review. Cancer Sci. 2016; 107:690-99. https://doi.org/10.1111/ cas.12910. PMID:26892980

2. Brown E, Hebra A, Jenrette J, Hudspeth M. Successful treatment of late, recurrent wilms tumor with highdose chemotherapy and autologous stem cell rescue in third complete response. J Pediatr Hematol Oncol. 2010; 32:e241-43. https://doi.org/10.1097/ MPH.0b013e3181e5e25b. PMID:20628317

3. Dome JS, Perlman EJ, Graf N. Risk stratification for wilms tumor: current approach and future directions. Am Soc Clin 
Oncol Educ Book. 2014; 215-23. https://doi.org/10.14694/ EdBook_AM.2014.34.215. PMID:24857079

4. Breslow NE, Olson J, Moksness J, Beckwith JB, Grundy P. Familial Wilms' tumor: a descriptive study. Med Pediatr Oncol. 1996; 27:398-403. https://doi. org/10.1002/(SICI)1096-911X(199611)27:5<398::AIDMPO2>3.0.CO;2-H. PMID:8827065

5. Grundy PE, Breslow NE, Li S, Perlman E, Beckwith JB, Ritchey ML, Shamberger RC, Haase GM, D’Angio GJ, Donaldson M, Coppes MJ, Malogolowkin M, Shearer P, et al, and National Wilms Tumor Study Group. Loss of heterozygosity for chromosomes $1 \mathrm{p}$ and $16 \mathrm{q}$ is an adverse prognostic factor in favorable-histology Wilms tumor: a report from the National Wilms Tumor Study Group. J Clin Oncol. 2005; 23:7312-21. https://doi.org/10.1200/ JCO.2005.01.2799. PMID:16129848

6. Messahel B, Williams R, Ridolfi A, A'hern R, Warren W, Tinworth L, Hobson R, Al-Saadi R, Whyman G, Brundler MA, Kelsey A, Sebire N, Jones C, et al, and Children's Cancer and Leukaemia Group (CCLG). Allele loss at 16q defines poorer prognosis Wilms tumour irrespective of treatment approach in the UKW1-3 clinical trials: a Children's Cancer and Leukaemia Group (CCLG) Study. Eur J Cancer. 2009; 45:819-26. https://doi.org/10.1016/j. ejca.2009.01.005. PMID:19231157

7. Grundy PE, Telzerow PE, Breslow N, Moksness J, Huff V, Paterson MC. Loss of heterozygosity for chromosomes $16 \mathrm{q}$ and $1 \mathrm{p}$ in Wilms' tumors predicts an adverse outcome. Cancer Res. 1994; 54:2331-33. PMID:8162576

8. Pan Z, He H, Tang L, Bu Q, Cheng H, Wang A, Lyu J, You H. Loss of heterozygosity on chromosome $16 q$ increases relapse risk in Wilms' tumor: a meta-analysis. Oncotarget. 2017; 8:66467-75. https://doi.org/10.18632/ oncotarget.20191. PMID:29029528

9. Knudson AG. Two genetic hits (more or less) to cancer. Nat Rev Cancer. 2001; 1:157-62. https://doi. org/10.1038/35101031. PMID:11905807

10. Hawthorn L, Cowell JK. Analysis of wilms tumors using SNP mapping array-based comparative genomic hybridization. PLoS One. 2011; 6:e18941. https://doi.org/10.1371/journal. pone.0018941. PMID:21544195

11. Ng PC, Henikoff S. Predicting deleterious amino acid substitutions. Genome Res. 2001; 11:863-74. https://doi. org/10.1101/gr.176601. PMID:11337480

12. Ramensky V, Bork P, Sunyaev S. Human non-synonymous SNPs: server and survey. Nucleic Acids Res. 2002; 30:3894-900. https://doi.org/10.1093/nar/gkf493. PMID:12202775

13. Gadd S, Huff V, Walz AL, Ooms AH, Armstrong AE, Gerhard DS, Smith MA, Auvil JM, Meerzaman D, Chen QR, Hsu $\mathrm{CH}$, Yan C, Nguyen C, et al. A Children's Oncology Group and TARGET initiative exploring the genetic landscape of Wilms tumor. Nat Genet. 2017; 49:1487-94. https://doi. org/10.1038/ng.3940. PMID:28825729

14. Skotnicka-Klonowicz G, Rieske P, Bartkowiak J, Szymik-
Kantorowicz S, Daszkiewicz P, Debiec-Rychter M. 16q heterozygosity loss in Wilms' tumour in children and its clinical importance. Eur J Surg Oncol. 2000; 26:61-66. https://doi.org/10.1053/ejso.1999.0742. PMID:10718182

15. Wittmann S, Zirn B, Alkassar M, Ambros P, Graf N, Gessler M. Loss of $11 \mathrm{q}$ and $16 \mathrm{q}$ in Wilms tumors is associated with anaplasia, tumor recurrence, and poor prognosis. Genes Chromosomes Cancer. 2007; 46:163-70. https://doi. org/10.1002/gcc.20397. PMID:17099873

16. Fukuzawa R, Anaka MR, Morison IM, Reeve AE. The developmental programme for genesis of the entire kidney is recapitulated in Wilms tumour. PLoS One. 2017; 12:e0186333. https://doi.org/10.1371/journal. pone.0186333. PMID:29040332

17. Marra AN, Li Y, Wingert RA. Antennas of organ morphogenesis: the roles of cilia in vertebrate kidney development. Genesis. 2016; 54:457-69. https://doi. org/10.1002/dvg.22957. PMID:27389733

18. Ito J, Johnson WW. Ultrastructure of Wilms' tumor. I. Epithelial cell. J Natl Cancer Inst. 1969; 42:77-99. PMID:4303833

19. Katz SM, Morgan JJ. Cilia in the human kidney. Ultrastruct Pathol. 1984; 6:285-94. https://doi. org/10.3109/01913128409018587. PMID:6485121

20. Duffy JL, Suzuki Y. Ciliated human renal proximal tubular cells. Observations in three cases of hypercalcemia. Am J Pathol. 1968; 53:609-16. PMID:5677142

21. Ong AC, Wagner B. Detection of proximal tubular motile cilia in a patient with renal sarcoidosis associated with hypercalcemia. Am J Kidney Dis. 2005; 45:1096-99. https:// doi.org/10.1053/j.ajkd.2005.02.019. PMID:15957140

22. Boerwinkle C, Marshall JD, Bryant J, Gahl WA, Olivier KN, Gunay-Aygun M. Respiratory manifestations in 38 patients with Alström syndrome. Pediatr Pulmonol. 2017; 52:48793. https://doi.org/10.1002/ppul.23607. PMID:28029746

23. Yang Y, Cochran DA, Gargano MD, King I, Samhat NK, Burger BP, Sabourin KR, Hou Y, Awata J, Parry DA, Marshall WF, Witman GB, Lu X. Regulation of flagellar motility by the conserved flagellar protein CG34110/ Ccdc135/FAP50. Mol Biol Cell. 2011; 22:976-87. https:// doi.org/10.1091/mbc.e10-04-0331. PMID:21289096

24. Raidt J, Wallmeier J, Hjeij R, Onnebrink JG, Pennekamp P, Loges NT, Olbrich H, Häffner K, Dougherty GW, Omran $\mathrm{H}$, Werner C. Ciliary beat pattern and frequency in genetic variants of primary ciliary dyskinesia. Eur Respir J. 2014; 44:1579-88. https://doi.org/10.1183/09031936.00052014. PMID:25186273

25. Geremek M, Ziętkiewicz E, Bruinenberg M, Franke L, Pogorzelski A, Wijmenga C, Witt M. Ciliary genes are down-regulated in bronchial tissue of primary ciliary dyskinesia patients. PLoS One. 2014; 9:e88216. https://doi. org/10.1371/journal.pone.0088216. PMID:24516614

26. Kim TW, Kim YJ, Kim HT, Park SR, Lee MY, Park YD, Lee CH, Jung JY. NQO1 Deficiency Leads Enhanced 
Autophagy in Cisplatin-Induced Acute Kidney Injury Through the AMPK/TSC2/mTOR Signaling Pathway. Antioxid Redox Signal. 2016; 24:867-83. https://doi. org/10.1089/ars.2015.6386. PMID:26935540

27. Olbrich H, Cremers C, Loges NT, Werner C, Nielsen KG, Marthin JK, Philipsen M, Wallmeier J, Pennekamp P, Menchen T, Edelbusch C, Dougherty GW, Schwartz O, et al. Loss-of-Function GAS8 Mutations Cause Primary Ciliary Dyskinesia and Disrupt the Nexin-Dynein Regulatory Complex. Am J Hum Genet. 2015; 97:546-54. https://doi. org/10.1016/j.ajhg.2015.08.012. PMID:26387594

28. Jeanson L, Thomas L, Copin B, Coste A, Sermet-Gaudelus I, Dastot-Le Moal F, Duquesnoy P, Montantin G, Collot N, Tissier S, Papon JF, Clement A, Louis B, et al. Mutations in GAS8, a Gene Encoding a Nexin-Dynein Regulatory Complex Subunit, Cause Primary Ciliary Dyskinesia with Axonemal Disorganization. Hum Mutat. 2016; 37:776-85. https://doi.org/10.1002/humu.23005. PMID:27120127

29. Lewis WR, Malarkey EB, Tritschler D, Bower R, Pasek $\mathrm{RC}$, Porath JD, Birket SE, Saunier S, Antignac C, Knowles MR, Leigh MW, Zariwala MA, Challa AK, et al. Mutation of Growth Arrest Specific 8 Reveals a Role in Motile Cilia Function and Human Disease. PLoS Genet. 2016; 12:e1006220. https://doi.org/10.1371/journal. pgen.1006220. PMID:27472056

30. Evron T, Philipp M, Lu J, Meloni AR, Burkhalter M, Chen W, Caron MG. Growth Arrest Specific 8 (Gas8) and G protein-coupled receptor kinase 2 (GRK2) cooperate in the control of Smoothened signaling. J Biol Chem. 2011; 286:27676-86. https://doi.org/10.1074/jbc.M111.234666. PMID:21659505

31. Shi X, Garcia G 3rd, Van De Weghe JC, McGorty R, Pazour GJ, Doherty D, Huang B, Reiter JF. Erratum: superresolution microscopy reveals that disruption of ciliary transition-zone architecture causes Joubert syndrome. Nat Cell Biol. 2017; 19:1379-1379. https://doi.org/10.1038/ ncb3622. PMID:29087383

32. Wang L, Dynlacht BD. The regulation of cilium assembly and disassembly in development and disease. Development. 2018; 145:1-13. https://doi.org/10.1242/dev.151407. PMID:30224385

33. Khan NA, Willemarck N, Talebi A, Marchand A, Binda MM, Dehairs J, Rueda-Rincon N, Daniels VW, Bagadi M, Thimiri Govinda Raj DB, Vanderhoydonc F, Munck S, Chaltin P, Swinnen JV. Identification of drugs that restore primary cilium expression in cancer cells. Oncotarget. 2016; 7:9975-92. https://doi.org/10.18632/oncotarget.7198. PMID:26862738

34. Vertii A, Bright A, Delaval B, Hehnly H, Doxsey S. New frontiers: discovering cilia-independent functions of cilia proteins. EMBO Rep. 2015; 16:1275-87. https://doi. org/10.15252/embr.201540632. PMID:26358956

35. Pala R, Alomari N, Nauli SM. Primary Cilium-Dependent
Signaling Mechanisms. Int J Mol Sci. 2017; 18:2272-91. https://doi.org/10.3390/ijms18112272. PMID:29143784

36. Pressey JG, Anderson JR, Crossman DK, Lynch JC, Barr FG. Hedgehog pathway activity in pediatric embryonal rhabdomyosarcoma and undifferentiated sarcoma: a report from the Children's Oncology Group. Pediatr Blood Cancer. 2011; 57:930-38. https://doi.org/10.1002/pbc.23174. PMID:21618411

37. Oue T, Uehara S, Yamanaka H, Takama Y, Oji Y, Fukuzawa M. Expression of Wilms tumor 1 gene in a variety of pediatric tumors. J Pediatr Surg. 2011; 46:2233-38. https:// doi.org/10.1016/j.jpedsurg.2011.09.004. PMID:22152856

38. Wang Y, Zhou CJ, Liu Y. Wnt Signaling in Kidney Development and Disease. Prog Mol Biol Transl Sci. 2018; 153:181-207. https://doi.org/10.1016/ bs.pmbts.2017.11.019. PMID:29389516

39. Chung E, Deacon P, Marable S, Shin J, Park JS. Notch signaling promotes nephrogenesis by downregulating Six2. Development. 2016; 143:3907-13. https://doi.org/10.1242/ dev.143503. PMID:27633993

40. Chung E, Deacon P, Park JS. Notch is required for the formation of all nephron segments and primes nephron progenitors for differentiation. Development. 2017; 144:4530-39. $\quad$ https://doi.org/10.1242/dev.156661. PMID:29113990

41. Li H, Rao A, Hogan PG. Structural delineation of the calcineurin-NFAT interaction and its parallels to PP1 targeting interactions. J Mol Biol. 2004; 342:1659-74. https://doi.org/10.1016/j.jmb.2004.07.068. PMID:15364589

42. Nguyen AH, Béland M, Gaitan Y, Bouchard M. Calcineurin a-binding protein, a novel modulator of the calcineurinnuclear factor of activated T-cell signaling pathway, is overexpressed in wilms' tumors and promotes cell migration. Mol Cancer Res. 2009; 7:821-31. https://doi. org/10.1158/1541-7786.MCR-08-0402. PMID:19531566

43. Lemos FO, Ehrlich BE. Polycystin and calcium signaling in cell death and survival. Cell Calcium. 2018; 69:37-45. $\quad$ https://doi.org/10.1016/j.ceca.2017.05.011. PMID:28601384

44. Ravichandran K, Edelstein CL. Polycystic kidney disease: a case of suppressed autophagy? Semin Nephrol. 2014; 34:27-33. https://doi.org/10.1016/j. semnephrol.2013.11.005. PMID:24485027

45. Lv W, Booz GW, Wang Y, Fan F, Roman RJ. Inflammation and renal fibrosis: recent developments on key signaling molecules as potential therapeutic targets. Eur J Pharmacol. 2018; 820:65-76. https://doi.org/10.1016/j. ejphar.2017.12.016. PMID:29229532 